\title{
Research Paper \\ Evaluation of structural equation modeling explaining happiness based on health status, financial distress and social support with mediated role of self-esteem and positive thinking in middle-aged women
}

\author{
Masoumeh Shojaei ${ }^{1}$, Firozeh Zangeneh Motlagh $^{2}$, AliReza Zolfaghari ${ }^{2}$ \\ 1. Ph.D Student in Psychology, Department of Psychology, Islamic Azad University, Arak, Iran \\ 2. Assistant Professor, Department of Psychology, Islamic Azad University, Arak, Iran
}

Citation: Shojaei M, Zangeneh Motlagh F, Zolfaghari A.R. Evaluation of structural equation modeling explaining happiness based on health status, financial distress and social support with mediated role of selfesteem and positive thinking in middle-aged women. J of Psychological Science. 2021; 20(104): 1437-1454.

URL: https://psychologicalscience.ir/article-1-1001-fa.html
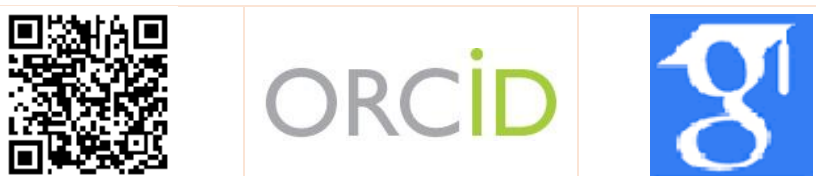

$\underline{10.52547 / J P S .20 .104 .1437}$
A R T I C L E I N F O

Keywords:

Happiness,

Health,

Financial Distress, Social Support, Self-Esteem, Positive Thinking

Received: 22 Oct 2020 Accepted: 19 Nov 2020 Available: 23 Oct 2021

\section{A B S T R A C T}

Background: According to the performed research, different variables effects on the middle-aged women happiness but health status, financial distress, social support, self-esteem and positive thinking role have ignored as the perfect modeling.

Aims: This research has performed for studying type of happiness, health status, financial distress, social support, self-esteem and positive thinking role in middle-aged women whom live in Arak.

Methods: This research has been as the descriptive, correlation and structural equations. Statistical society included women whom are 36-55 years old and live in Arak in 2019. 408 persons were selected for performing research. All of them filed in the public health questionnaires (Goldberg and Hiller, 1979), financial distress (Provitz et al., 2006) social support (Zimet et al., 1988) self-esteem (Rosenberg, 1963) positive thinking (Ingram and Wisnicki, 1988) and Oxford happiness (Hills and Argil, 2002). Pearson correlation methods and structural equations modeling were used for data analysis.

Results: The results indicated that health variable $(0.12,0.15$ and 0.18$)$ financial distress $(-0.18,-$ 0.36 and -0.22$)$ and social support $(0.46,0.55$ and 0.43$)$ has significant effects on self-esteem, positive thinking and happiness. In addition, that self-esteem and positive thinking variables has direct and significant effects on happiness. The results indicated that three variables, health variable $(0.13)$ financial distress (-0.10) social support (0.12) has indirect and significant effect on self-esteem, positive thought and happiness on middle-aged women.

Conclusion: Thhis modeling is used for improving middle-aged women happiness and the principles of happiness, different types of social support, health status, financial distress, self-esteem and positive thinking and effective antecedents can be addressed in educational, social and communication media. A systematic review of previous research reveals that many factors explain self-injury behaviors in individuals. The measurement of self-injury and its relevant statements is of great importance; however, this aspect is disregarded in Persian research.

* Corresponding Author: Firozeh Zangeneh Motlagh, Assistant Professor, Department of Psychology, Islamic Azad University, Arak, Iran.

E-mail: firoozeh.zangeneh@gmail.com

Tel: (+98) 9188620768

2476-5740/ () 2021 The Authors. This is an open access article under the CC BY-NC-ND license

(https://creativecommons.org/licenses/by-nc/4.0/). 


\section{Extended Abstract}

\section{Introduction}

Middle age is one of the stages of human evolution. Middle age is a natural event and normal time in life span and generally begins in the fourth decade of a person's life. Researchers reviewing the literatures of middle age demonstrate that middle age occurs specifically between the ages of 40 and 60 , but there is no exact border for this stage of life (Mc Load, 2013). Middle-aged women encounter with a number of needs during this period. Maslow divided these needs into three categories: basic needs, psychological needs, and self-actualization needs (Fritas and Leonard, 2011). In this study, the variables related to these three needs in middle-aged women are investigated. So, three variables of social support, financial crisis and health status as basic needs and predictor variables, two variables of positive thinking and self-esteem as psychological needs and mediating variables and happiness as self-actualization and criteria variables are included in the conceptual model of this study. The following is a brief description of each of these variables.

Happiness refers to the levels at which people judge the desires of their lives. It means how much a person loves and enjoys his life (Avarandeh, Eftekhar Saadi2, Bakhtearpour, Heidari and Askari, 2019). Various factors affect the happiness of middle-aged women. These factors can be internal or external, internal factors include attitude, commitment, positive thinking and self-esteem (Seligman, 2005). On the other hand, many external factors including economic power, education, income, health status and social support affect happiness (Lio et al, 216).

Self-esteem is one of the factors affecting happiness that refers to the evaluation of the individual towards himself (Vishkalashki and yeshodara, 2012). Researchers believe that people with high self-esteem have higher happiness (Bajaj, Goyta and Sangoyta, 2019). Peterson (2008) believes that positive thinking is one of the key factors in achieving happiness. Positive thinking refers to an orientation in which positive consequences are usually expected and these consequences are considered as fixed, general and internal factors (Hogendorn et al, 2012). Research evidence suggests that positive-minded people are happier than negative-thinking people. (Mercola, 2002).

Health status is one of the basic needs of middle-aged women in today's life. According to the World Health Organization (WHO), the state of health of individuals is a state of complete physical, mental and social well-being and not just the absence of disease or disability, which has a dynamic interaction between these three dimensions (Chng, Chio and Cho, 2009). Research evidence suggests that middleaged women with higher health status have higher self-esteem traits and positive thinking. (Kim and Hore, 2019).

Financial crisis or financial distress is one of the most important needs of middle-aged women and it is a type of economic imbalance that reduces people's happiness. The results also show that people with better economic status have higher positive thinking and live a more positive and thoughtful life (Aram Patzy, Burger and Withon, 2015). Thus, economic stress and financial crisis and distress are reduced for middle-aged women with a stable and regular income, and the lower the economic stress, the higher the level of women's happiness. (Graham 2012).

Social support from various sources is one of the most important variables related to Maslow's basic needs that middle-aged women need to it. Social support provides an increase in quality of life and a shield resistant to difficult life events (Wils and Ayteneh, 202). Research shows that social support increases self-esteem (Aykens and Soccer, 2010) and positive thinking (Kim and Hore, 2019). Given the above, the main question of the present study is whether the structural model of happiness based on health status, financial crisis and social support with the mediating role of self-esteem and positive thinking has a good fit? 


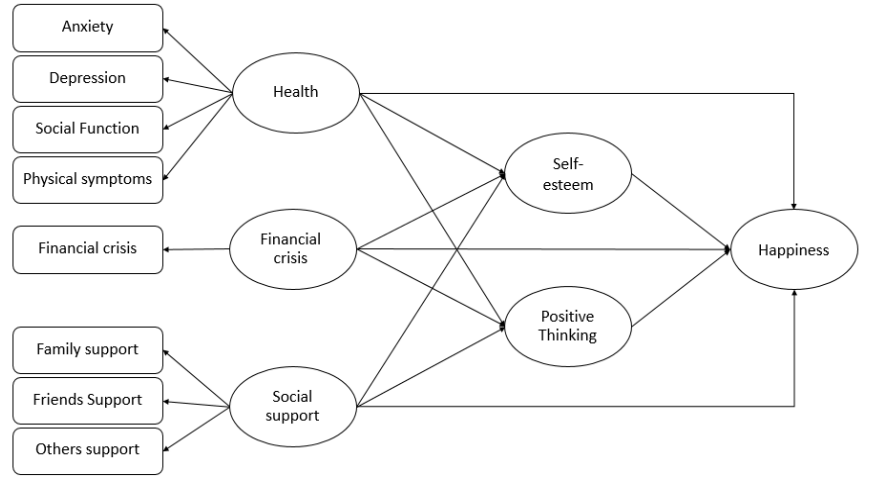

Figure 1: The Conceptual Model of Study

\section{Method}

This research is a descriptive-correlational study and structural equations modeling (SEM). The study population consisted of all middle-aged women in Arak. A total of 450 middle-aged women in Arak who met the inclusion criteria were selected by nonrandom available sampling method. The research questionnaires were: Goldberg and Hiller (1979) General Health Questionnaire (GHQ) which has 28 items and examines 4 components of depression, anxiety, social dysfunction and physical symptoms. Each of these components has 7 items. Each person's overall score is the sum of the scores of the four subscales. The 8-item Oxford Happiness Questionnaire (OHQ) was designed by Hills and Argil (2002) to assess happiness as a one-dimensional construct. The 12-item Zimet et al.'s (1988) Social Support Questionnaire (SSQ) was also used to assess the subject's perception of social support sources. Ingram and Wisnicky (1988) Positive Thinking Questionnaire (PTQ) consisting of 30 questions was used to assess positive thinking. In addition, the Rosenberg Self-Esteem Questionnaire (1965), which has 10 items, was used. The financial crisis questionnaire of Provitz et al. (2006) was another scale that consisted of 8 items and was used in this study.

\section{Results}

The results of demographic finding indicate that among the participants in the study, 69 people in the age range of 36 to 40,176 people in the age range of 41 to 45,107 people in the age range of 46 to 50 and 56 people in the age range of 51 they are up to 55 years old. Also, among the participants in the study, 194 (47.5\%) were employed and 214 (52.5\%) were housewives. In addition, among the participants in the study, 49 (12\%) were illiterate, 105 (25.7\%) had a middle-school education, $123(30.1 \%)$ had a diploma, and $84(20.6 \%)$ had a bachelor's degree. And 47 people $(11.5 \%)$ had master and higher. Descriptive findings related to variables are shown in the table below.

Table 1. Descriptive statics of study variables $(n=408)$

\begin{tabular}{|c|c|c|c|c|c|}
\hline \multicolumn{2}{|c|}{ Variables } & $\bar{M}$ & SD & Skewness & Kurtosis \\
\hline \multirow{4}{*}{ Health status } & Physical symptoms & 11.97 & 5.06 & -0.526 & -0.805 \\
\hline & Anxiety & 11.95 & 5.19 & -0.397 & -0.833 \\
\hline & Social function & 12.44 & 5.15 & -0.524 & -0.819 \\
\hline & Depression & 12.40 & 4.01 & -0.255 & -0.730 \\
\hline \multicolumn{2}{|c|}{ Financial crisis } & 30.63 & 17.64 & -0.681 & -1.045 \\
\hline \multirow{3}{*}{ Social support } & Friends support & 19.69 & 5.67 & -0.728 & -0.426 \\
\hline & Family support & 20.02 & 5.40 & -0.784 & -0.277 \\
\hline & Others support & 19.21 & 5.61 & -0.500 & -0.690 \\
\hline \multicolumn{2}{|c|}{ Self-esteem } & 30.59 & 6.77 & -0.848 & -0.414 \\
\hline \multicolumn{2}{|c|}{ Positive thinking } & 109.17 & 16.44 & -0.865 & -0.399 \\
\hline \multicolumn{2}{|c|}{ Happiness } & 31.28 & 9.15 & -0.680 & -0.474 \\
\hline
\end{tabular}

Pearson correlation method was also used to examine the relationships between variables. The results of Pearson correlation showed that the variables of depression, anxiety, social functioning, physical symptoms and financial crisis had a positive and significant relationship with social support, self- esteem, positive thinking and happiness. Also, the variables of social support, self-esteem and positive thinking had a positive and significant relationship with happiness. But the financial crisis variable had a negative and significant relationship with happiness. 


\section{Monthly Journal of Psychological Science}

It is noteworthy that all correlations were significant at the level of $p<0.01$.

On the other hand, the results of SEM showed that all three variables of health, financial crisis and social support had direct and significant effects on selfesteem, positive thinking and happiness. Self-esteem and positive thinking variables had direct and significant effects on happiness. The results also showed that the three variables of health, financial crisis and social support had an indirect and significant effect on the happiness of middle-aged women through self-esteem and positive thinking. The effect was negative for the financial crisis variable and positive for health and social support. The fit indices of the final model are as follows.

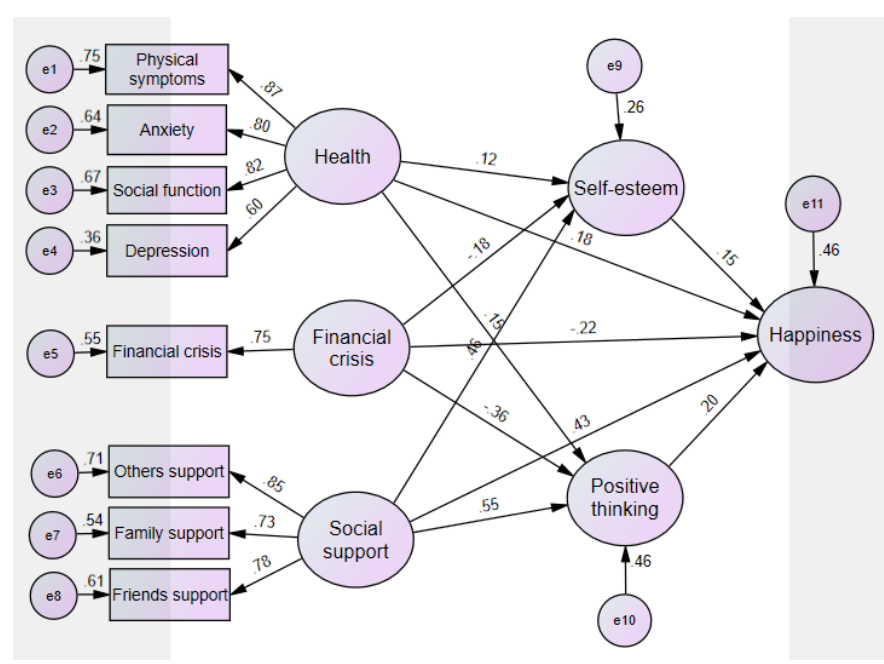

Figure 2: Structural model of study

\section{Conclusion}

The aim of this study was to evaluate the structural model of happiness based on health status, financial crisis and social support with a mediating role of selfesteem and positive thinking for middle-aged women in Arak. The results showed that health status and social support have a positive, direct and significant effect on self-esteem, positive thinking and happiness. While the financial crisis had a negative, direct and significant effect. On the other hand, the results showed that health status, financial crisis and social support have an indirect effect on happiness through self-esteem and positive thinking. Based prior studies, it is highlighted that, if a person enjoys his life, he uses more appropriate behaviors to
Vol. 20, No. 104, Autumn(November) 2021

improve it, otherwise he engages in self-destructive behaviors that can be destructive. In this way, health behaviors are an effective predictor of happiness. Therefore, when people are in good health and can pay attention to their worth and self-esteem along with this health, the level of happiness in them is strengthened.

Also, when people are in good health, they are better able to think and make decisions and are more optimistic about what will happen in the future, which makes them happier. In addition, when middle-aged women suffer from financial crisis, they experience low self-esteem and self-esteem, which can lead to unhappiness and happiness. In other words, financial distress in itself reduces happiness in middle-aged women, but if a little self-esteem is accompanied by financial distress, it can somewhat reduce the effect of the financial crisis on happiness. On the other hand, it can be said that social support through self-esteem has been able to have an indirect and significant effect on happiness.

Therefore, when middle-aged women have the full support of family, friends and others, they consider themselves more valuable, which increases and promotes their self-confidence and self-esteem, which in turn reinforcements their happiness. Also, when the social support of middle-aged women is appropriate, this support leads to positive thinking that these two structures themselves can make them happy in life. Moreover, when these women have the necessary support, they have a positive perspective toward life that will bring more happiness.

\section{Ethical Considerations}

Compliance with ethical guidelines: This article is taken from the doctoral dissertation of the first author in the field of psychology at Islamic Azad University of Arak. Participants consciously and voluntarily participated in the research. The principle of confidentiality was observed in the research.

Funding: This study was conducted as a $\mathrm{PhD}$ thesis with no financial support.

Authors' contribution: The first author was the senior author, the second were the supervisors and the third and forth was the advisors.

Conflict of interest: the authors declare no conflict of interest for this study.

Acknowledgments: The Authors would like to thank the supervisors and consultants of this study and all the participants in this study for their patience. 
ارزيابى مدل معادلات ساختارى تبيين شادكامى بر اساس وضعيت سلامت، بحران مالى و حمايت اجتماعى با نقش واسطهاى عزتنفس و تفكر مثبت در زنان ميانسال

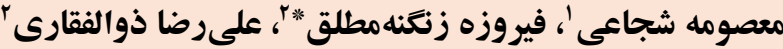

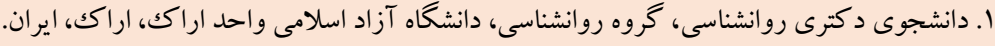

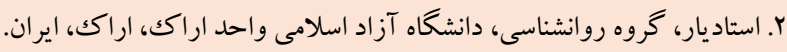

جكيده

زمينه: مرور نظاممند يُوهشها حاكى از اين است كه در تبيين شاد كامى زنان ميانسال متغيرهاى مختلفى تأثير مى گذارد، اما نقش وضعيت سلامت، بحر ان مالى، حمايت اجتماعى، عزتنفس و تفكر مثبت به عنوان يكك مدل يكيارجه مغفول مانده است.

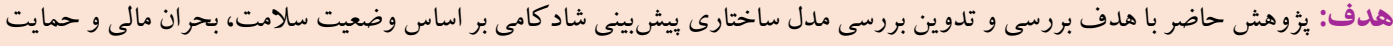

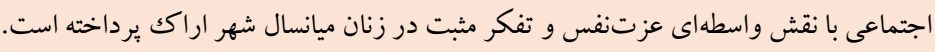

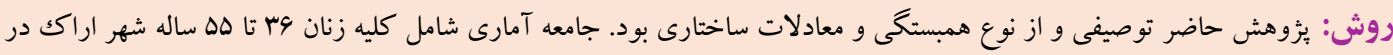

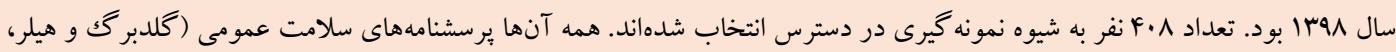

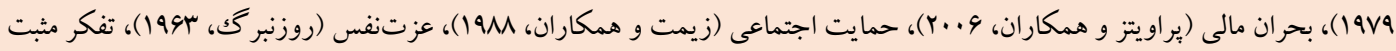

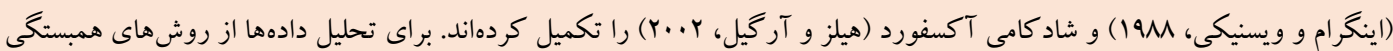

بيرسون و مدل معادلات ساختارى استفاده شد.

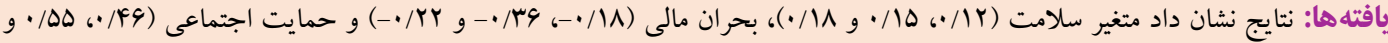

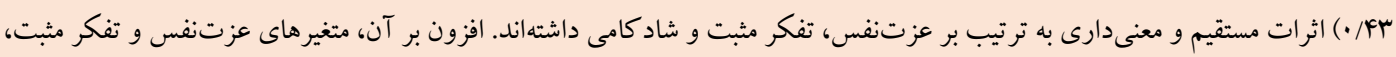

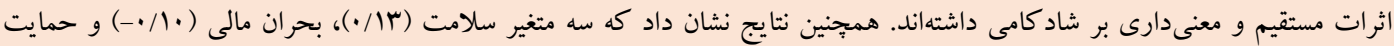
اجتماعى (Y/ / ) بر شاد كامى زنان ميانسال اثر غير مستقيم و معنى دارى دارند.

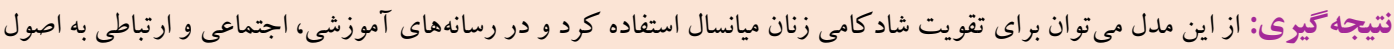

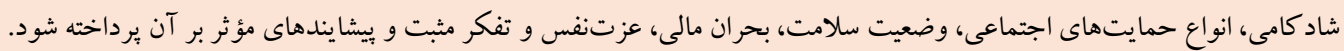

مشخصات مقاله

كليدوازمها: شاد كامى، سلامت،

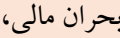

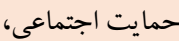
عزتنفس، تفكر مثبت

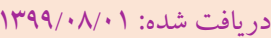

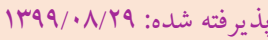

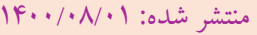

* نويسنده مسئول: فيروزه زنغنهمطلق، استاديار، گروه روانشناسى، دانشاه آزاد اسلامى واحد اراك، اراك، ايران. رايانامه: firoozeh.zangeneh@gmail.com 
عزتنفس به عنوان نيازهاى روانشناختى و متغير هاى ميانجى و شاد كامى به

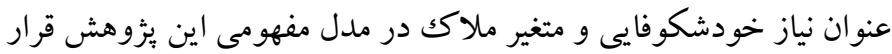

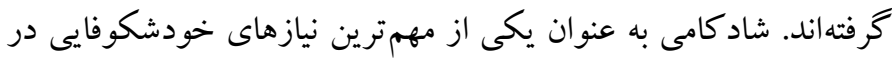
زنان ميانسال مطرح شد. شادكامى به سطوحى اشاره دارد كه افراد

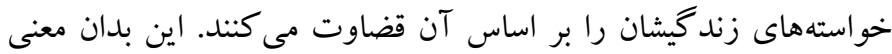

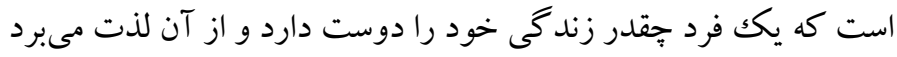
(آورنده، افتخارصعادى، بختياريور، حيدرى و عسكرى، \هجا). عوامل

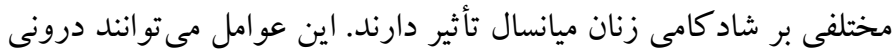

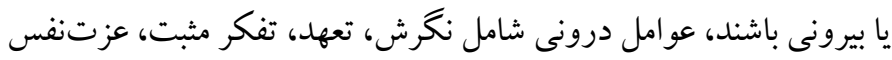
و... هستند. از اين رو در بين اين عوامل عزتنفس و تفكر مثبت بيش از

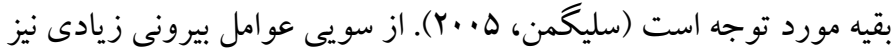
در اين امر دخيل هستند، اين عوامل شامل قدرت اقتصادى، تحصيلات،

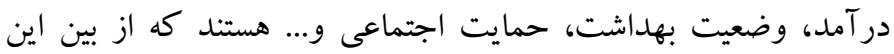
عوامل وضعيت سلامت، بحران مالى و حمايت اجتماعى به عنوان عوامل

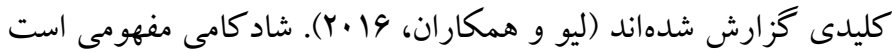
كه نقش مهمى در بهزيستى روانشناختى، سلامت اجتماعى و همجنين خودشكوفايى افراد دارد. از نظر وينهوون شاد كامى به سطوحى اشاره دارد

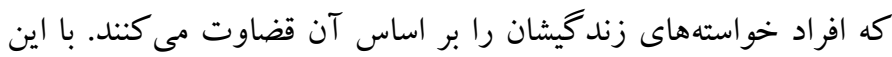
تعاريف شادكامى يكك مفهوم انتزاعى و ذهنى است و هر فرد الكوى منحصر به فردى براى رسيدن به شادكامى دارد (به نقل از هيزومى، الهوردى يور، جعفر آبادى و صفائيان، 1ه إب).

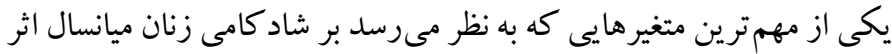
دارد، عزتنفس آنهاست. عزت نفس به ارزشيابى فرد نسبت به خود اشاره

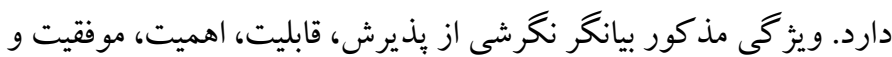
ارزش فردى است كه معمولاً افراد آن را حفظ مى كنند (ويشالاكشى و يشودارا، Y Y. Y). عزتنفس از عوامل تعديل كننده فشار روانى - اجتماعى

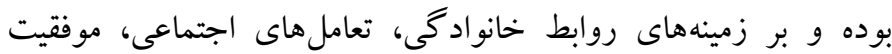
تحصيلى، تصوير بدنى و احساس خود ارزشمندى كلى مبتنى است و ميزان اهميت اين زمينها با توجه به تفاوتهاى فردى و رشد فرد تغيير مى كند

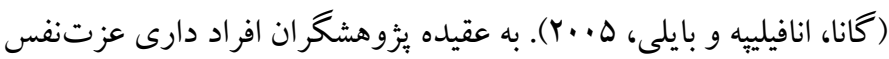

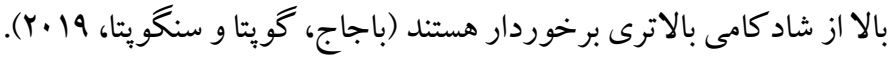

مقلفمه

مراحل تحول در جنبههاى مختلف زندگى به صورت متوالى و بیىدريى متشكل از تغييرات و تحولات ناشى از ساخت نيروهاى درونى شئى شكوفا

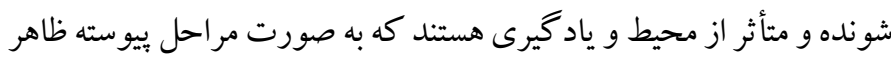

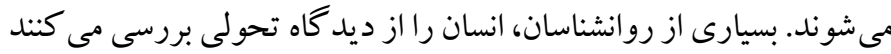

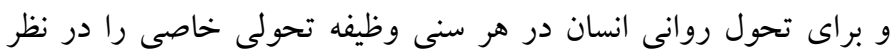
مى گيرند و عقيده دارند كه افراد براى اينكه هويت و شخصيت سالم داشته باشند لازم است تكاليف خاص هر سن را با موفقيت انجام دهند تا با شخصيت خود حس مثبت و شادمانى داشته باشند (كورىهارا، م+..r). دورة ميانسالى يكى از مراحل تحول انسان است. ميانسالى رويداد طبيعى و

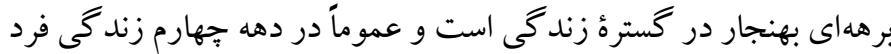
آغاز مىشود. يزوهشخران در مرور آثار مربوط به دوران ميانسالى، نشان

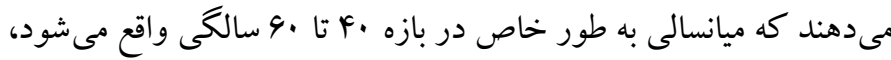

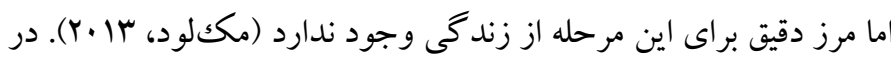

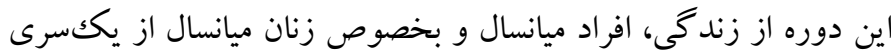
نيازها برخوردارند، به گونهاى كه به نظر مىرسد اين نيازها مىتوانند بر

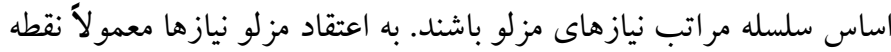

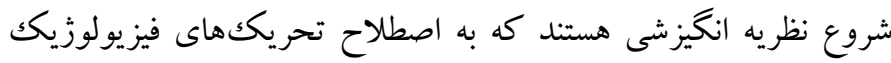

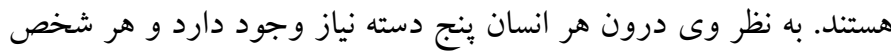
براى ارضاى نيازهاى خود به ترتيب زير مى كوشد: ا. نيازهاى زيستى

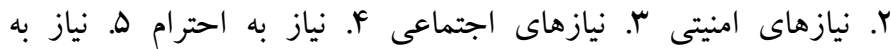

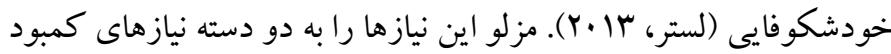

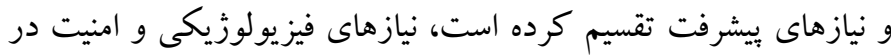
رده بايين و نيازهاى اجتماعى، احترام، خودشكوفايى را در رده بالا قرار داد. نيازهاى رده بالا در درون فرد ارضا شده و نيازهاى رده بايين به وسيله عوامل بيرونى ارضا مىشوند. همجِنين وى بر اين عقيده است كه مىتوان اين دستهبندى را به سه دسته نيازهاى اساسى، نيازهاى روانشناختى و نيازهاى

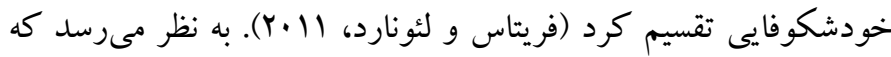
مىتوان از اين نظريه مدلى را جهت نيازهاى زنان ميانسال با توجه به متغيرهاى روانشناسى استخراج نمود. بر اين اساس سه متغير حمايت اجتماعى، بحر انى مالى و وضعيت سلامت به به

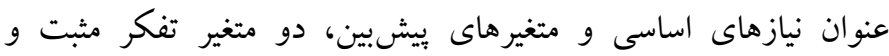


هميشه افزايش نمى يابد. به صورت كلى با افزايش سن زنان ميانسال، استرس

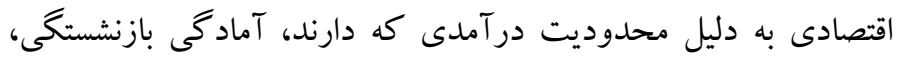

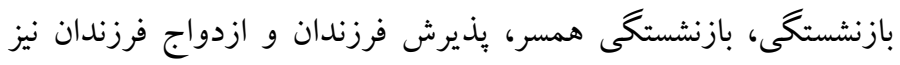
افزايش مىيابد. از اين رو استرس اقتصادى و بحران و يريشانى مالى با درآمد بِيدار و منظم براى زنان ميانسال كاهش مى يابد و هرجه استرس

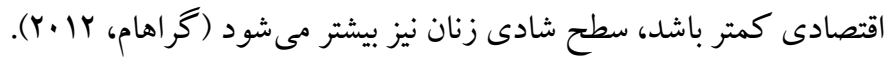

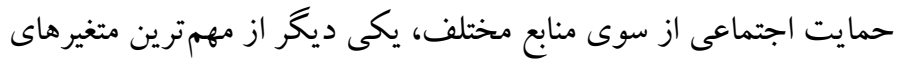
مرتبط با نيازهاى اساسى مزلو است. اصطلاح حمايت اجتماعى، اغلب در

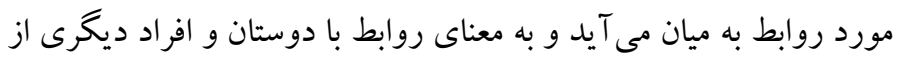
جمله خانو اده است كه به نوبه خود در زمان نياز و يا بحران است كه باعث

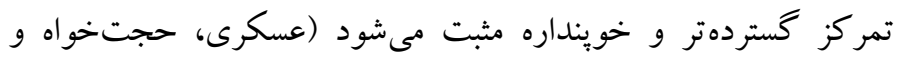

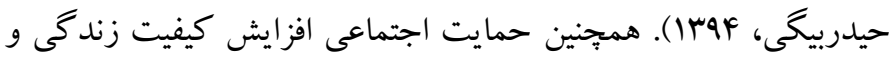
يكك سبر مقاوم در برابر وقايع سخت زند گحى را فراهم مى كند (ويلز و آينته، Y Y. Y). تحقيقات نشان داده است بين سطوح حمايت اجتماعى ادارككشده و عزت نفس رابطه مثبت و معنادارى به دست آمده است (آيكيز و ساكر،

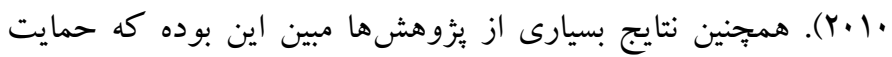

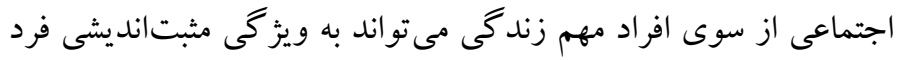
كمكك نمايد (كيم و هور، 19 19. (Y).

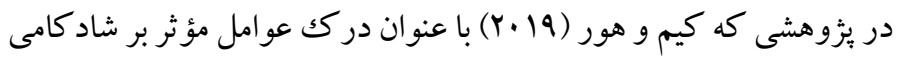
زنان ميانسال در كره بر اساس سلسله مراتب نيازهاى مزلو به اين نتيجه دست يافت كه وضعيت سلامت، بحران مالى و حمايت اجتماعى بر عزتنفس و

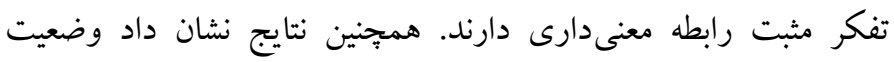

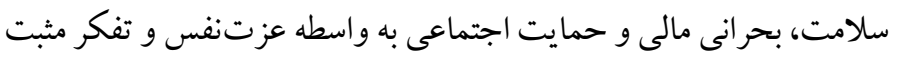
بر شادكامى زنان ميانسال اثر غير مستقيم و معنى دارى دارند. افزون بر آن بين تفكر مثبت و عزتنفس با شادكامى رابطه معنىدار و اثر مستقيم و

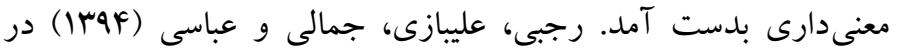
يزووهشى با عنو ان بررسى رابطه عزتنفس و حمايت اجتماعى با سلامت

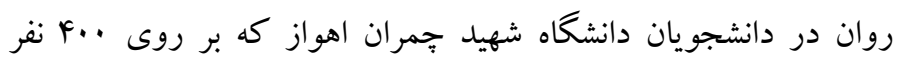

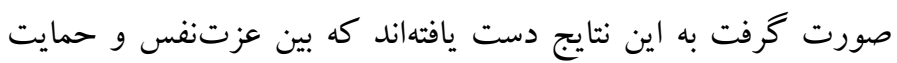

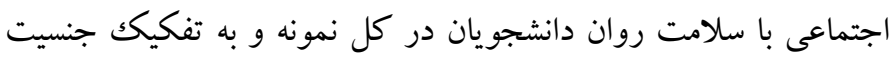

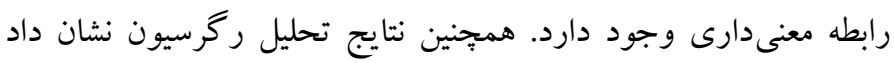
متغيرهاى ويشبين عزتنفس و حمايت اجتماعى در سلامتروان
از سويى بترسون (YN+1) عقيده دارد كه تفكر مثبت يكى از عوامل كليدى براى رسيدن به شاد كامى است. تفكر مثبت به جهت گيرى اشاره دارد كه

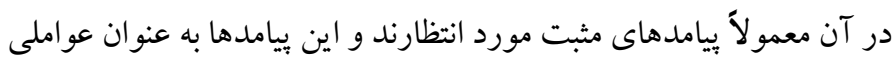

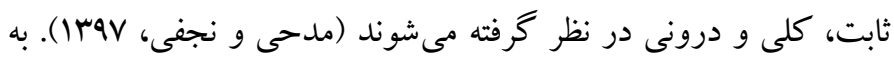

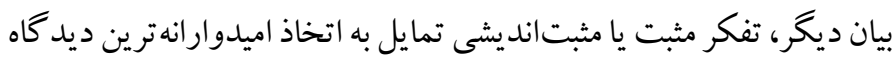

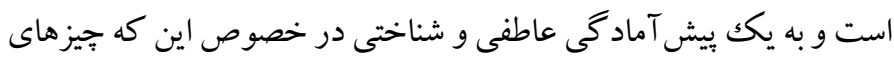
خوب مهمتر از جيزهاى بد است، اشاره دارد، كه اين خود مستلزم آن است

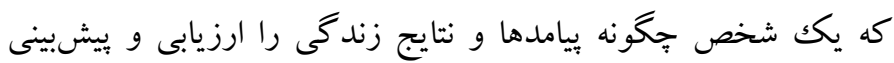

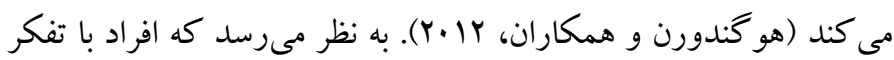
مثبت از مهارتهاى اجتماعى مطلوبترى برخوردارند، معاشرتى هستند و

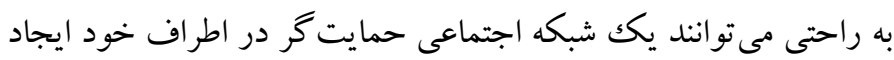
نمايند. همجنين افراد مثبتانديش، از شاد كامى مطلويترى نسبت به به افراد

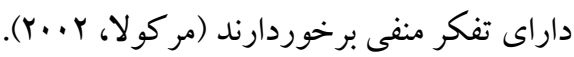
افزون بر آن وضعيت سلامت به عنوان يكى از نيازهاى اساسى افراد در زندگى امروزى و همجنين در نظريه مزلو مطرح است. از نظر سازمان

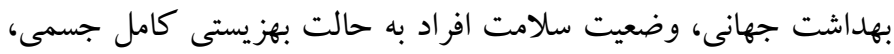

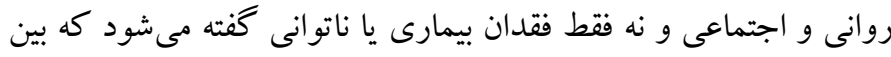

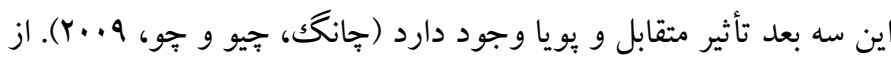

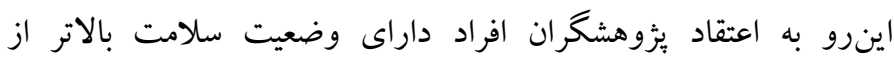
ويزگى هاى عزتنفس و ارزشمندى خود بالاترى برخوردار هستند

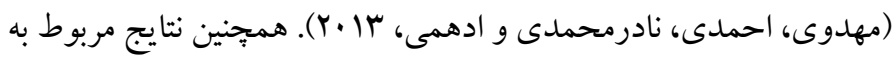
سلامت نشان از آن است كه افر ادى كه از وضعيت سلامتى بهترى برخوردار

$$
\text { هستند تفكر مثتى دارند (كيم و هور، 19 19). }
$$

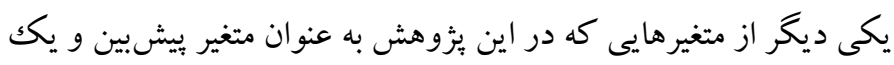

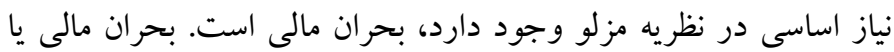
ير يشانى مالى به نوعى عدم تعادل اقتصادى است كه ميزان شادى افراد را

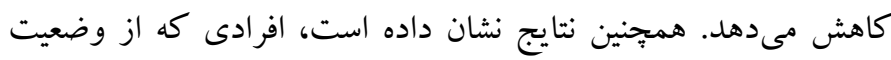

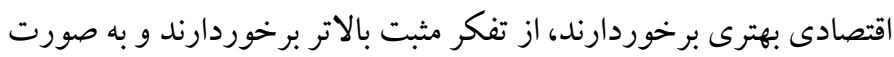

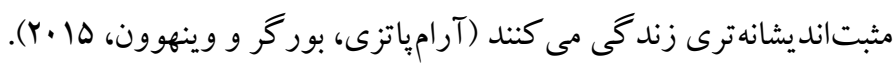
از سويى نتايج نشان داده است، افرادى كه سطح در آمدشان از مقدارى بالاتر باشد كه وضعيت خيلى بالايى داشته باشند، اين امر ديخر بر شاديشان

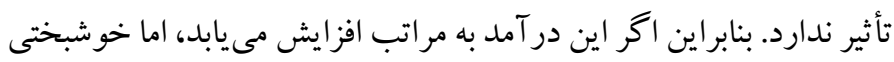


بسارى از آنها در معرض بحران ميانسالى قرار دارند حائز اهميت است لذا

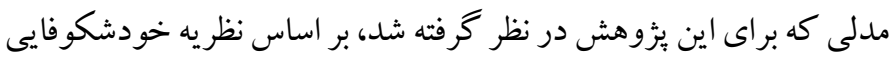

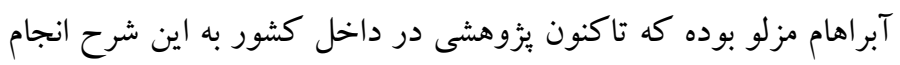

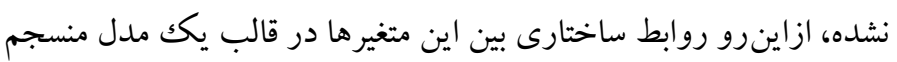

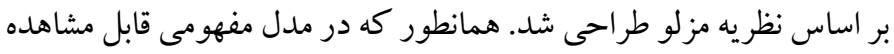

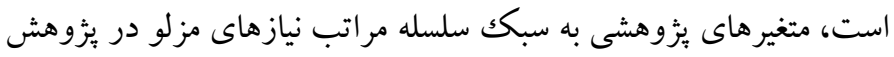

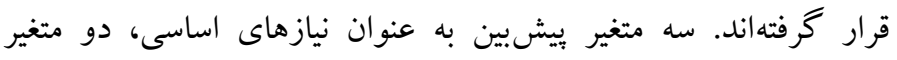
واسطهاى به عنوان نيازهاى روانشناختى و دو متغير ملاكك به عنوان نيازهاى

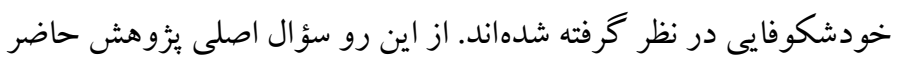
اين است كه آيا مدل ساختارى شاد كامى بر اساس وضعيت سلامت، بحران مالى و حمايت اجتماعى با نقش واسطهاى عزتنفس و تفكر مثبت از

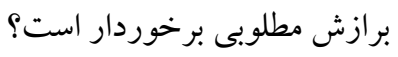

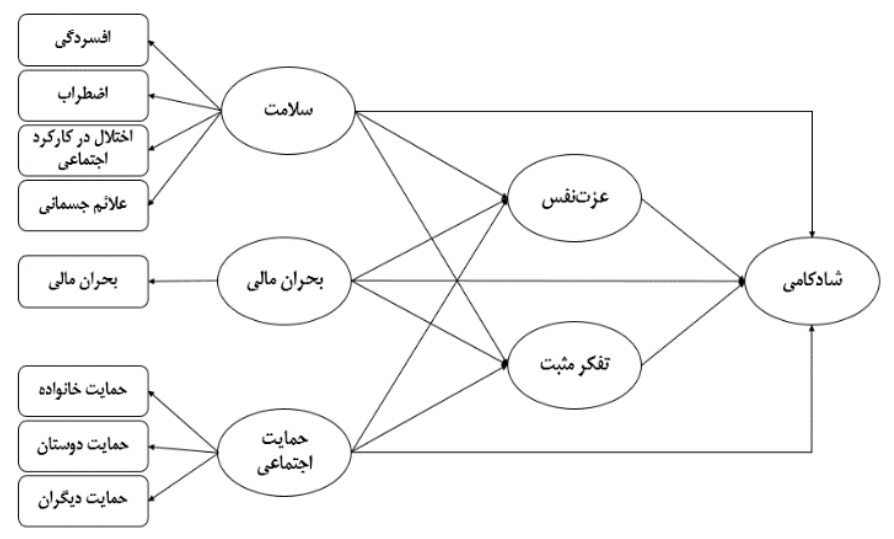

شكل 1. مدل مفهومى يثووه

روش

الف) طرح بثزوهش و شر كت كنند كان: اين يثزوهش توصيفى از نوع همبستگى و معادلات ساختارى است. جامعه بزوهش متشكل از كليه زنان

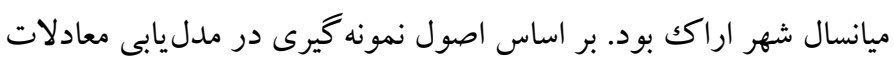

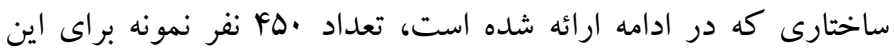

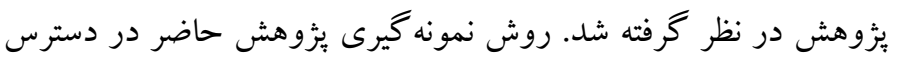

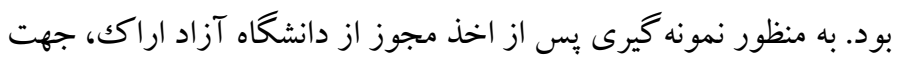

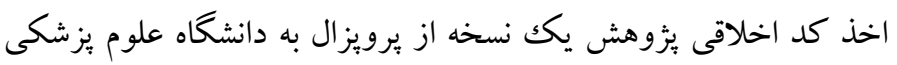

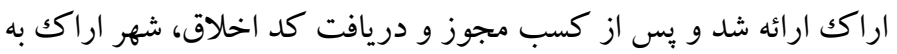

دانشجويان نقش دارند. توان، جهانى و رفيعى (rar|) در يثوهش خود با عنوان ارتباط بين عزتنفس و شادكامى در دانشجويان دانشگاه علوم

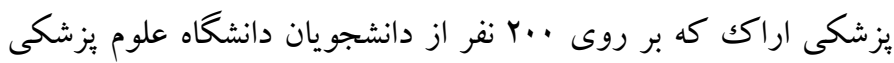

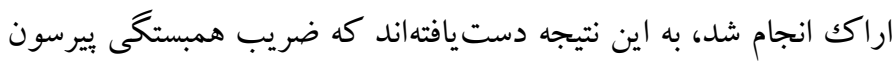

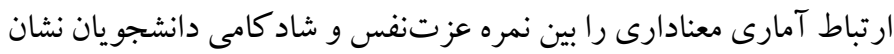
داد. در نتيجه مىتوان كفت عزتنفس و شاد كامى دانشجويان دانشكاه علوم يزشكى اراكك در حد بالايى قرار دارد. همجينين به نظر مىرسد

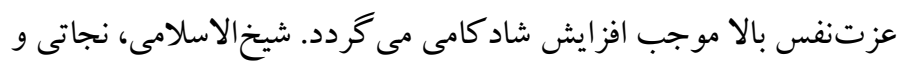

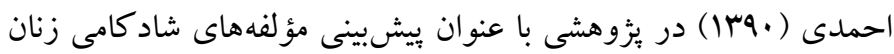
متأهل از طريق عزتنفس و روابط زناشويى كه بر روى له نفر از زنان

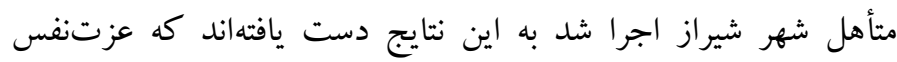

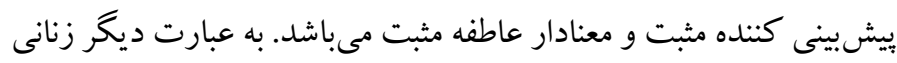
كه از عزتنفس بيشترى برخوردارند، عواطف مثبت بيشترى نيز تجربه

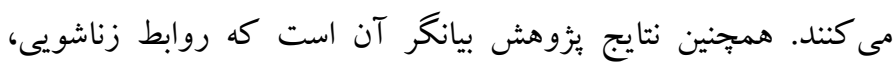

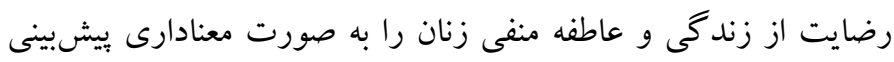

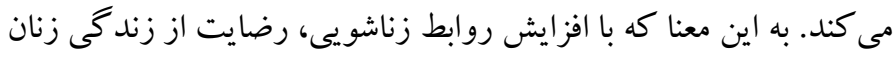
افزايش و عواطف منفى آنها كاهش مى يابد.

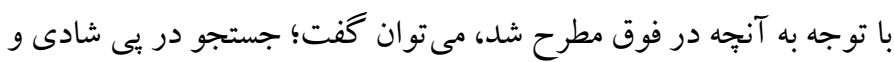

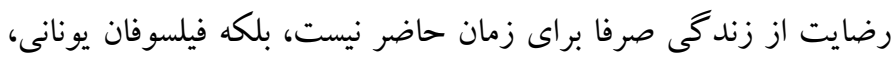

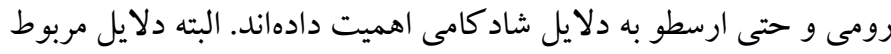
به شاد كامى را نمى توان به عنوان دلايلى جهانشمول تلقى كرد جر اكه هر

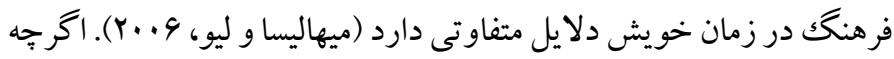

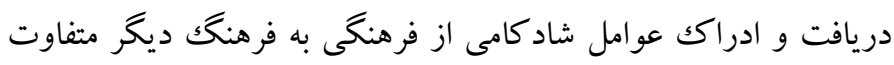

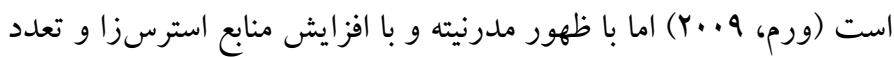
نقش افراد، جستجوى شادى در همه جو امع و فر هنگك ها سرعت زيادى يافته

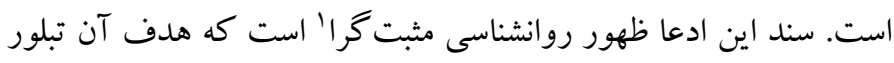

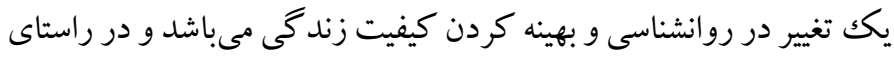
اين هدف بررسى بيشايندهاى شاد كامى به كانون توجه در اين حوزه تبديل

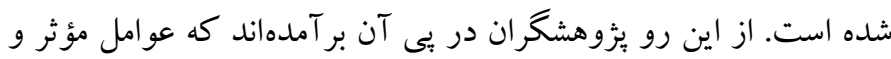

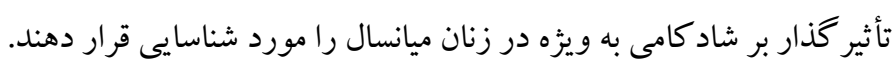

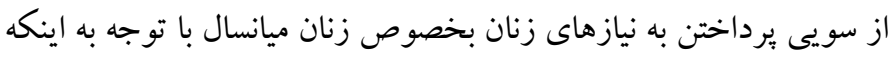

\footnotetext{
${ }^{1}$. positive psychology
} 
بايين تر حاكى از بهداشت عمومى و يا سلامتروان بهتر است. نمرهزارى

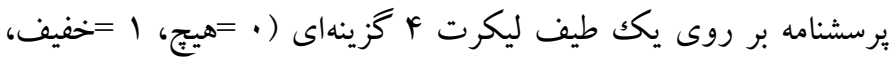

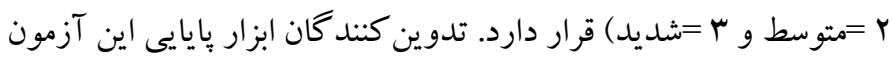

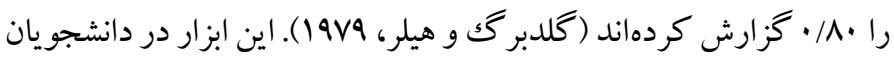

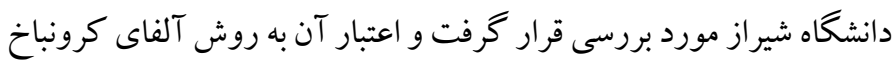

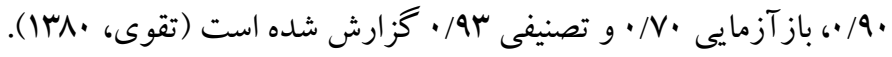
ضريب اعتبار اين يرسشنامه در بيزوهش حاضر به روش آلفاى كرونباخ

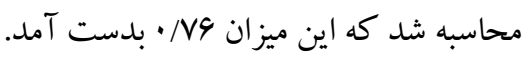

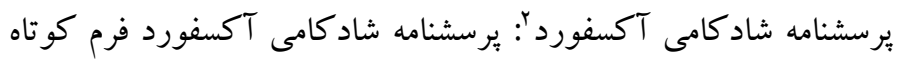

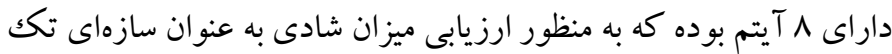

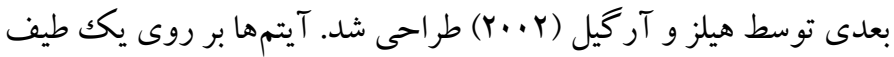
ليكرت 9 گزينهاى (1=كاملاً مخالفم تا $9=$ =كاملاً موافقم) قرار دارند.

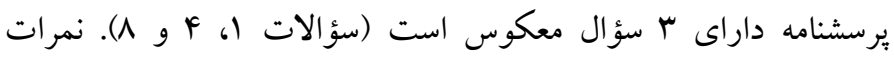
يرسشنامه در دامنه ^ تا ي F قرار دارند و نمرات بالاتر در اين آزمون نشاندهنده ميزان شادى بيشتر است. ضريب اعتبار اين آزمون به روش

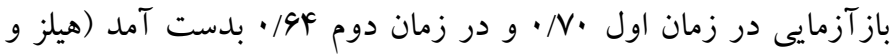

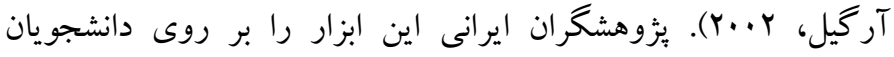

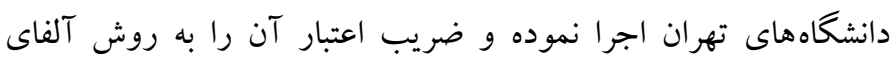

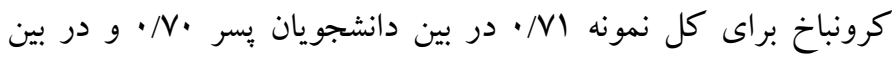
دانشجويان دختر VI/ • گزارش كردهاند (دهشيرى، اكبرى بلوطبنگان،

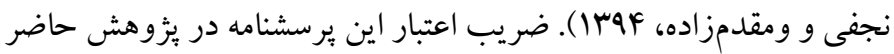
به روش آلفاى كرونباخ محاسبه شد كه اين ميزان سل/م • بدست آمد. برسشنامه حمايت اجتماعى "ّ: اين ابزار توسط زيمت و همكاران (19M1)

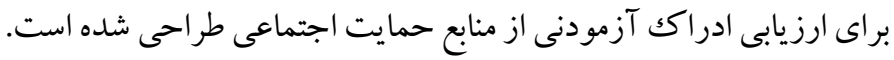

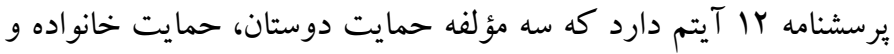

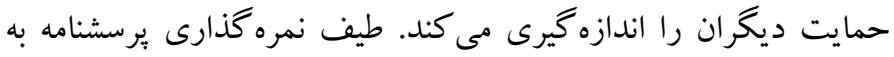

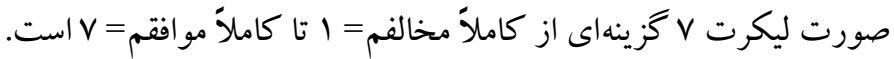
يرسشنامه داراى نمره كل مىباشد و اين نمره از مجموع نمرات بر بآ آيتم بدست مى آيد. بايايى ابزار در يُزوهشهاى مختلف بدست آمده است.

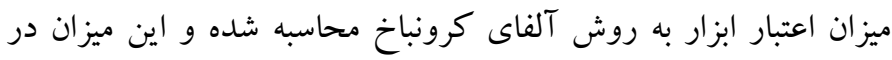

${ }^{3}$. Social Support Questionnaire
ب قسمت مركز، شمال و جنوب تقسيم شد و از هر قسمت • له خانم ميانسال به شيوه در دسترس انتخاب شد. دليل انتخاب •ها نفر اين بوده كه تعداد

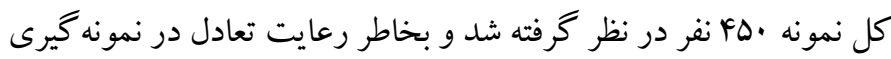
سه منطقه شهر اراكك اين تعداد انتخاب شد. حداقل حجم نمونه براى مدليابى معادلات ساختارى ..1 تا •ها نفر است. برخى يزوهش ها تعداد

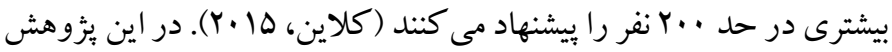
با توجه به حجم بالاى متغيرهاى يثوهش تعداد •وأنفر در نظر كرفته شده

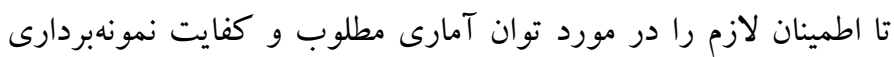

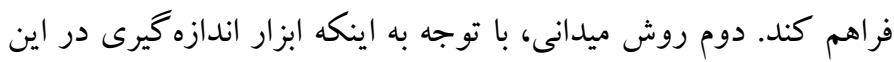

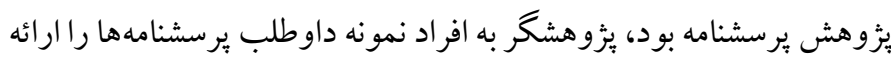

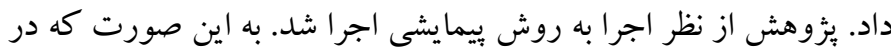

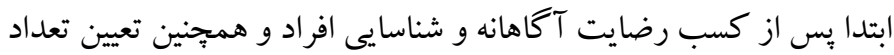
نمونه، يرسشنامهاى يزوهش بين اعضا توزيع شد. جنسيت زن، دامنه سنى

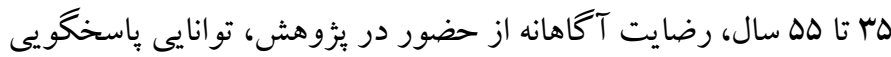
به سؤالات يرسشنامه از ملاككهاى ورود به يُزوهش بودهاند و ملاككهاى

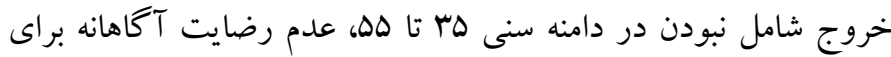

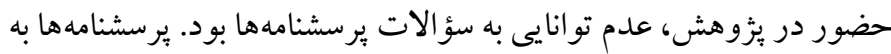

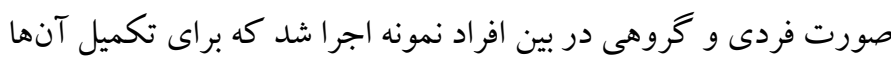
محدوديت زمانى لحاظ نشد.

ب) (بزار برسشنامه سلامت عمومى ': كلدبر گك و هيلر (19V9) برسشنامه سلامت عمومى را براى سرند كردن اختلالات روانى غير سايكوتيك در مراكز درمانى و جامعه طراحى و تدوين كردهاند. اين ابزار دارى شY آيتم است كه وضعيت سلامت افراد را در \& مؤلفه افسردگى، اضطراب، اختلال در كاركرد اجتماعى و علائم جسمانى مورد سنجش قرار مى دهد. هر كدام از مراز

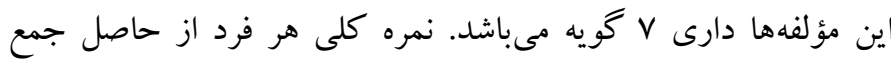

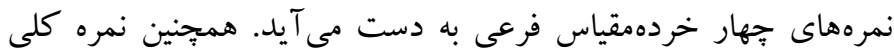
وضعيت سلامت فرد از حاصل جمع هر \& خردهمقياس بدست مى بـ آيد. از

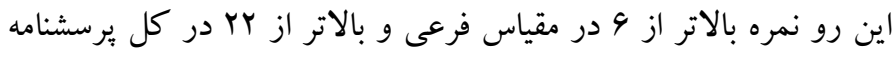
بيانگر اختلال در سلامت است. به عبارت ديخر در اين برسشنامه نمره

1. General Health Questionnaire

2. Oxford Happiness Questionnaire - Short Form 
ضريب بايايى اين يرسشنامه به روش بازآمايى هA/· بدست آمد

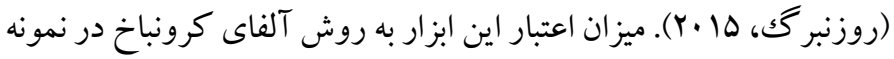

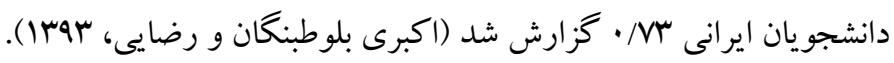

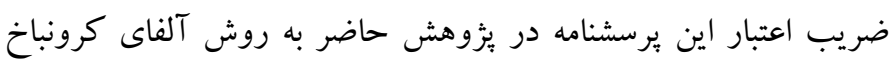

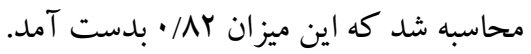

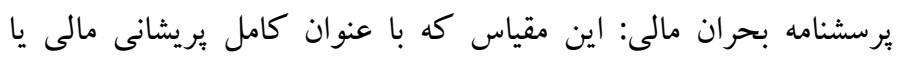

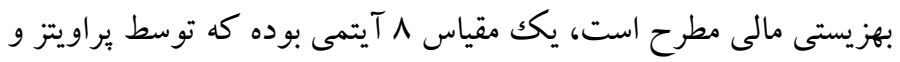

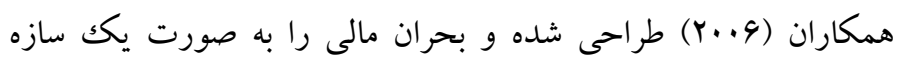

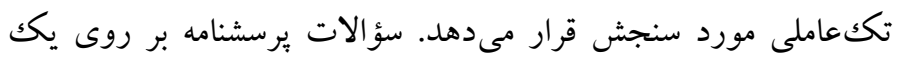
محور (از ا=بعضى اوقات تا • = =هميشه) قرار دارند. براى بررسى بايايى اين ابزار، تدوين كنند كان از روش همسانى درونى به كمك آلفاى كرونباخ

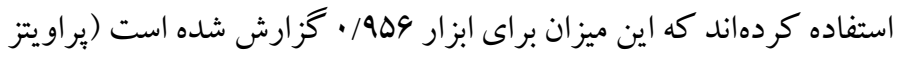

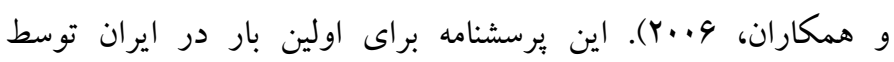

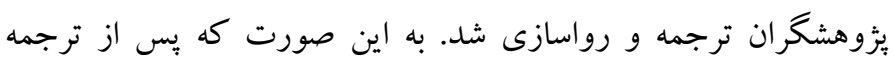

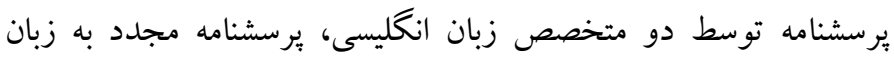

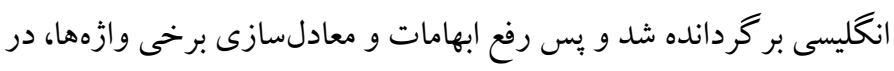

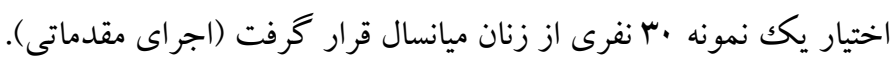

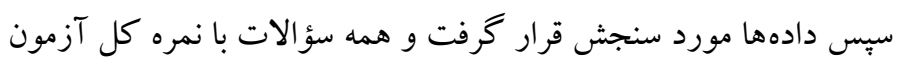

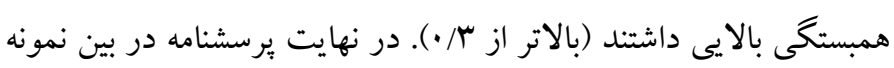
نهايى اجرا شد و مورد تجزيه و تحليل عاملى قرار كرفت كه نتايج تحليل

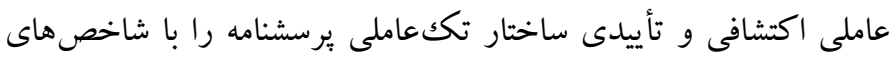

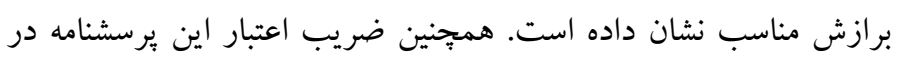

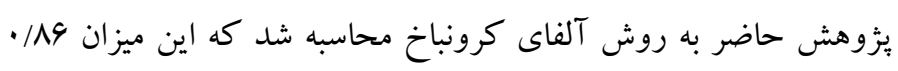
بدست آمد. يس از تكميل برسشنامهها، اطلاعات جمع آورى شده و وارد نرمافزار شد. براى تجزيه و تحليل اطلاعات از روشهاى آمار توصيفى (ميانخين و انحر اف معيار ) و آمار استنباطى شامل همبستخى بيرسون و و مدليابى معادلات ساختارى به كمك نرمافزارهاى SPSS و و

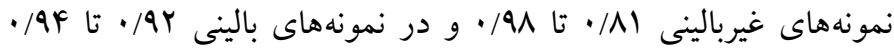

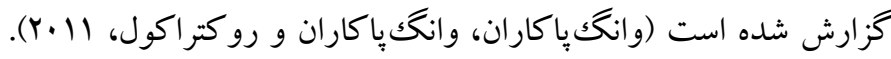

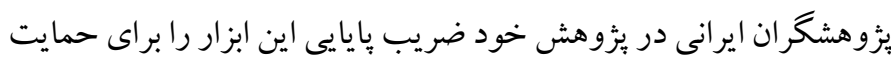

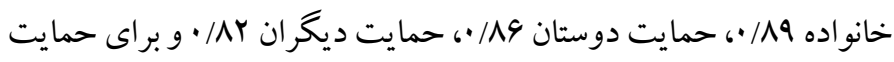

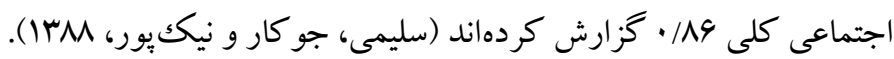
ضريب بايايى اين يرسشنامه در يُوهش حاضر به روش آلفاى كرونباخ

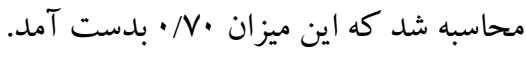

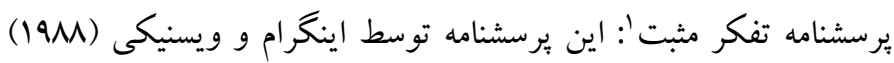

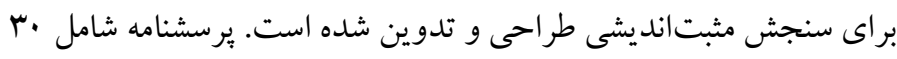

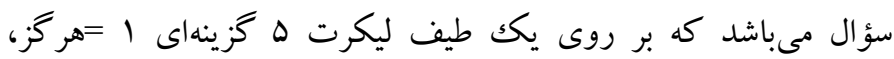

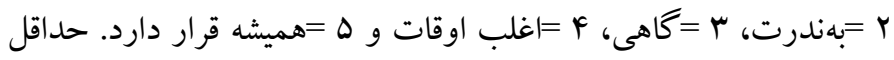

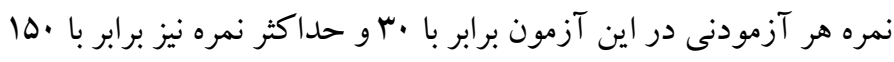

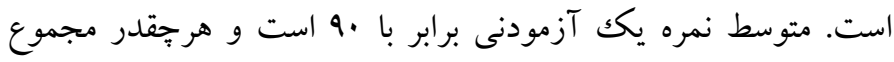

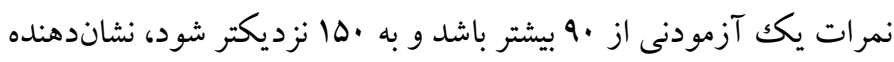
تفكر مثبت بالاتر آن آزمودنى است. به عقيده تدوين كنند كان، اين ابزار

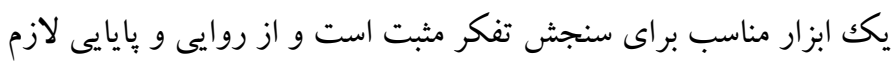
نيز برخوردار است (اينگرام و ويسنيكى،

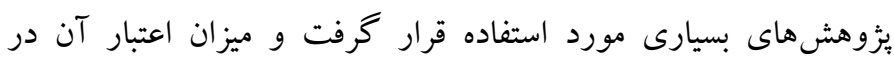

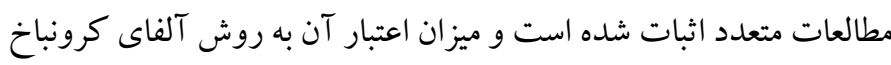

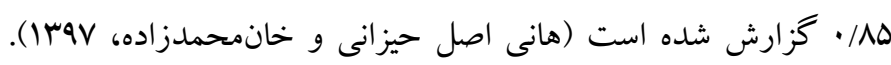

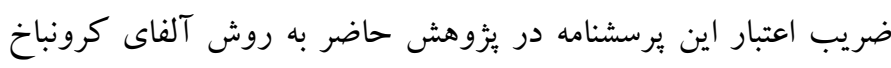

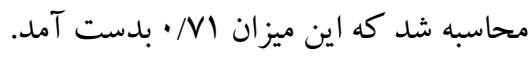

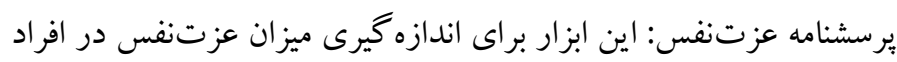

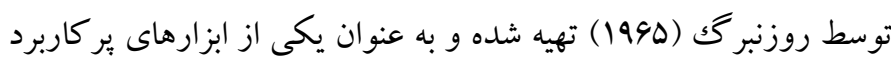
در زمينه سنجش عزتنفس بوده كه روايى و بايايى قابل قبولى دارد.

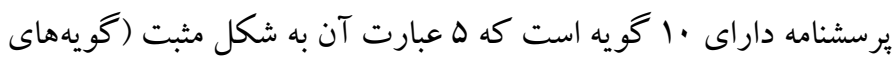

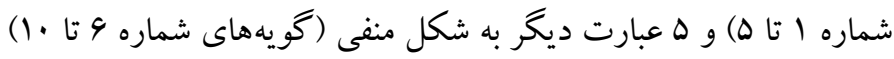

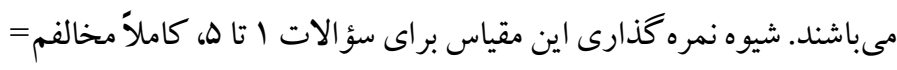

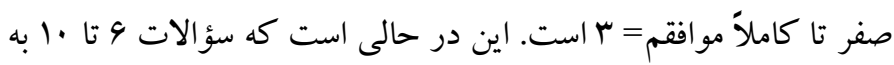

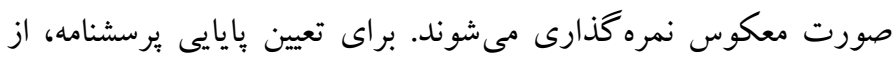

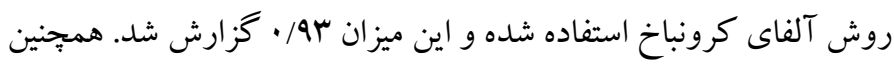

1. Positive Thinking Questionnaire 


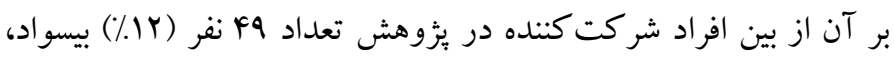

يافته ها

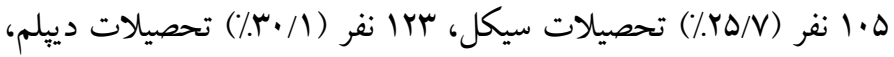

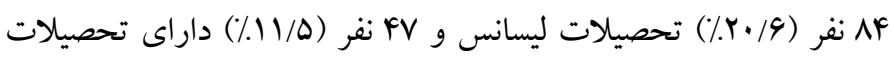
ارشد و بالاتر بودهاند. يافتهاى توصيفى مربوط به متغيرها در جدول زير لهري

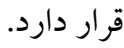

نتايج مربوط به يافتهاى جمعيتشناختى حاكى از آن است كه از بين افراد

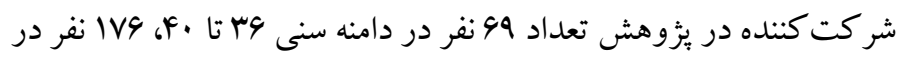

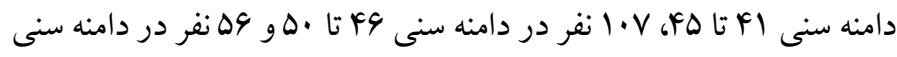

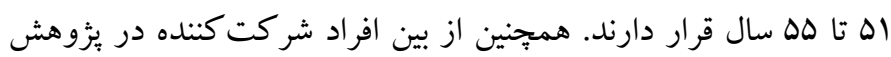

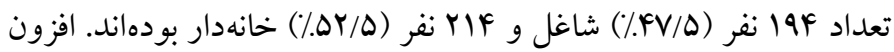

جدول ا. آمارههاى توصيفى متغير هاى بثوهش (تعداد م مع نفر)

\begin{tabular}{|c|c|c|c|c|c|c|}
\hline كشيدگى & كجى & انحر اف استاندارد & ميانگين & بيشترين نمره & كمترين نمره & متغيرها \\
\hline$-\cdot / \lambda \cdot \Delta$ & $-\cdot / \Delta Y G$ & $8 / .9$ & $11 / 9 V$ & $r$. & 1 & علائم جسمانى \\
\hline - & $-\cdot / r q V$ & $8 / 19$ & $11 / 90$ & r. & 1 & اضطراب \\
\hline$-\cdot / 1 / 9$ & $-\cdot / \Delta Y F$ & $8 / 10$ & $I Y / F F$ & r. & r & كار كرد اجتماعى \\
\hline$-\cdot / N r$. & $-\cdot / Y \Delta \Delta$ & $f / \cdot 1$ & $\mid r / F$ & r. & f & افسردگى \\
\hline$-1 / .4 \Delta$ & $\cdot / 911$ & IV/GF & $r \cdot / 9 r$ & 94 & 1. & بحر ان مالى \\
\hline$-\cdot$ ArG & $-\cdot /$ VYA & $\Delta / 9 \mathrm{~V}$ & $19 / 99$ & rA & $\checkmark$ & حمايت دوستان \\
\hline$-\cdot / r V V$ & $-\cdot / V \wedge F$ & $\Delta / F$. & $r \cdot / \cdot r$ & rA & $\wedge$ & حمايت خانواده \\
\hline-.199. & $-\cdot / \Delta \cdot$ & $8 / 91$ & $|9 / Y|$ & rA & $v$ & حمايت ديخران \\
\hline$-\cdot / F \mid f$ & $-\cdot / A F \Lambda$ & G/VV & $r \cdot / \Delta q$ & f. & 19 & عزتنفس \\
\hline$-\cdot / 499$ & $-\cdot / 190$ & $19 / 44$ & $1.9 / 18$ & ir. & vr & تفكر مثبت \\
\hline$-\cdot / F V F$ & $-\cdot / 91$ & $9 / 10$ & rI/rA & kq & ir & شاد كامى \\
\hline
\end{tabular}

واريانس بزركتر از حد مجاز · ا نبود. از اين رو مىتوان كفت مفروضه

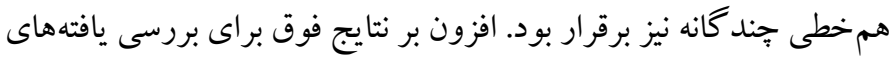

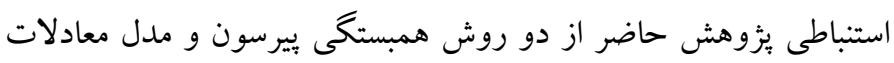

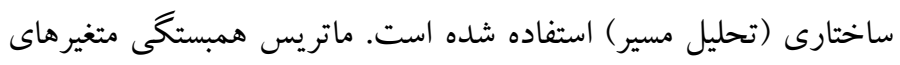
بُزوهش در جدول r بارائه شده است.

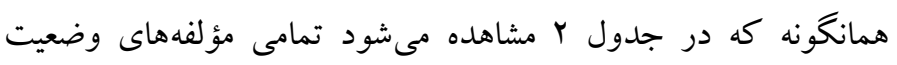

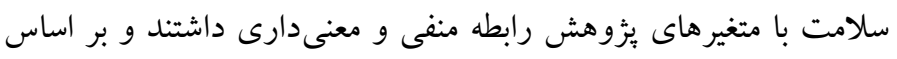
برسشنامه سلامت عمومى (GHQ) نمر ات بايين تر و منفى در مؤلفه ها نشان

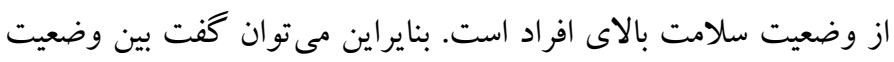

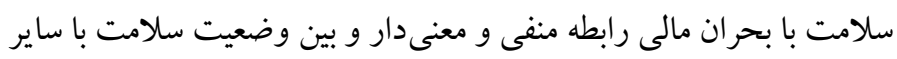
متغيرهاى يزووهش رابطه مثبت و معنىدارى وجود دارد. كليه همبستخى ها ونها

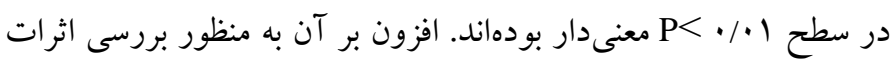

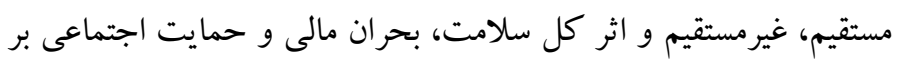
عزتنفس، تفكر مثبت و شاد كامى از تحليل مسير استفاده شد كه نتايج در

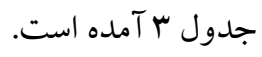

در جدول ا ميانگين، انحر اف استاندارد، كمترين و بيشترين نمره مربوط به متغيرهاى يزوهش ارائه شده است. ساير يافتهاى توصيفى مربوط به

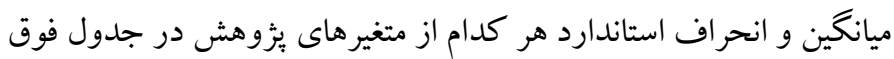

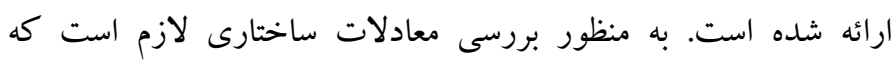

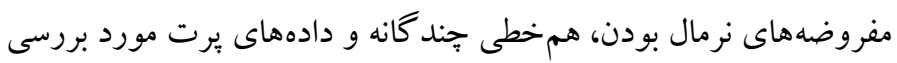

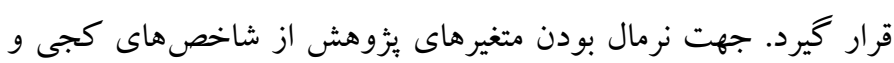

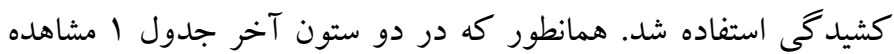

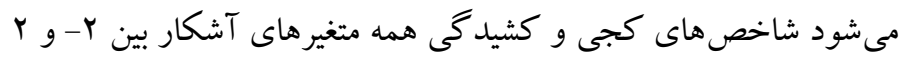

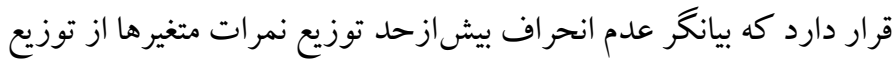

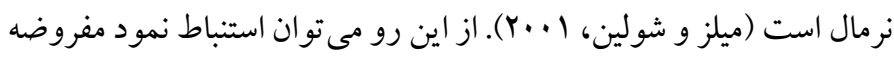

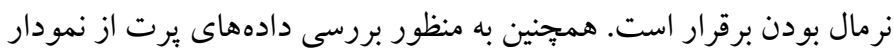

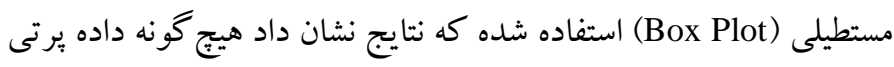
در ميان دادهها وجود ندارد. همجينين براى بررسى همخطى جند

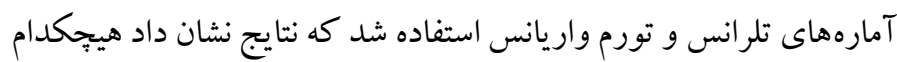

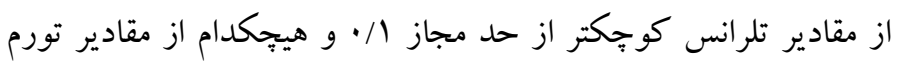


جدول r. ماتريس همبستغى متغيرهاى يثزوهش

\begin{tabular}{|c|c|c|c|c|c|c|c|c|c|c|c|}
\hline 11 & 1. & 9 & $\wedge$ & $v$ & 9 & $\Delta$ & F & $r$ & $r$ & 1 & متغير \\
\hline & & & & & & & & & & 1 & 1. علائم جسمانى \\
\hline & & & & & & & & & 1 & .1999 & r. اضطراب \\
\hline & & & & & & & & 1 & $.19 \Delta \Delta$ & $\cdot N \cdot r$ & r. كار كرد اجتماعى \\
\hline & & & & & & & 1 & $\cdot / \Delta \cdot V$ & - / FAF & $\cdot / \Delta 1 \Lambda$ & F. افسردگ \\
\hline & & & & & & 1 & $\cdot / 0$. & - /FFa & $\cdot 10 \cdot 9$ & $\cdot / \Delta \cdot F$ & هـ بحران مالى \\
\hline & & & & & 1 &.$- / 940$ & $-\cdot /$ FV & $-\cdot /$ VYq & $-\cdot /$ quF & $-\cdot / 49$. & 9. حمايت دوستان \\
\hline & & & & 1 &.$/ 94$. & $-\cdot 19 \cdot 9$ & $-\cdot / 4 \pi$ & $-\cdot / 4 q$. & $-\cdot / \mu \cdot r$ & $-\cdot /$ FFF & V. حمايت خانواده \\
\hline & & & 1 & $\cdot / \Delta V \mid$ &.$/ 901$ & -.1911 & $-\cdot / A \Delta r$ & $-\cdot / 499$ & $-\cdot M F r$ & $-\cdot /$ fir & ^ حمايت ديخران \\
\hline & & 1 & $\cdot / F A \Delta$ &.$/ 0.1$ & $\cdot / D 9 V$ & $-\cdot / \Delta T A$ & $-\cdot / 4 \cdot 9$ & $-\cdot / r V$ & גואי- & $-\cdot / \mu \cdot r$ & 9. عزتنفس \\
\hline & 1 & $\cdot / 919$ & $\cdot / \Delta Q Y$ &.$/ 99$. &.$/ 9 \Delta F$ & $-\cdot N \cdot r$ & $-\cdot / A A r$ & $-\cdot /$ \&V & $-\cdot /$ Fqq & $-\cdot / \Delta \cdot V$ & •ا. تفكر مثبت \\
\hline 1 & .1994 & . /DrG & .191. & .1949 &.$/ 991$ & $-\cdot / 9 \mathrm{~W}$ & $-\cdot / A A V$ &.$- / 949$ & $-\cdot / \uparrow \wedge$ & $-\cdot / \Delta r$ & 11. شاد كامى \\
\hline
\end{tabular}

جدول r. نتايج اثرات مستقيم، غير مستقيم و اثر كل سلامت، بحران مالى و حمايت اجتماعى بر عزتنفس، تفكر مثبت و شاد كامى

\begin{tabular}{|c|c|c|c|c|c|c|c|}
\hline \multicolumn{2}{|c|}{ اثرات كل } & \multicolumn{3}{|c|}{ اثرات غيرمستقيم } & \multicolumn{2}{|c|}{ اثرات مستقيم } & مسيرها \\
\hline \multirow{2}{*}{ معنى دارى } & \multirow{2}{*}{ اثر } & \multicolumn{2}{|c|}{ سطح اطمينان 9ه٪ } & \multirow{2}{*}{ اثر } & \multirow{2}{*}{ معنىدارى } & \multirow{2}{*}{ اثر } & \multirow{2}{*}{ به شاد كامى } \\
\hline & & حد بالا & حديايين & & & & \\
\hline$\cdot / \cdot l^{*}$ & $\cdot / \pi 1$ & $\cdot / V F$. &.$/ 110$ &.$/ 1 \pi$ & $\% / \cdots 1^{*}$ &.$/ 1$ & سلامت \\
\hline$\cdot / \cdot 1^{*}$ & $-\cdot / \mu r$ & - MFD & $\cdot / \cdot \Delta \Delta$ & $-\cdot / 1$ & $\% / \cdot 1^{*}$ & $-\cdot / Y Y$ & بحران مالى \\
\hline$\cdot / \cdot 1^{*}$ & $\cdot / \Delta \Delta$ & $\cdot|F F|$ &.$/ .91$ & . $/ Y r$ & $\cdot / \cdot 1^{*}$ &.$/ 4 \pi$ & حمايت اجتماعى \\
\hline$\cdot / \cdot r r^{*}$ &.$/ 10$ & --- & --- & --- & $/ \cdot Y Y^{*}$ &.$/ 10$ & عزتنفس \\
\hline$\cdot / \cdot 1^{*}$ & $\cdot / r$ & --- & --- & --- & $\cdot / \cdots 1^{*}$ & $\cdot / r$ & تفكر مثبت \\
\hline$\cdot / r \Delta^{*}$ & $\cdot / M r$ & --- & -- & --- & $\cdot / \cdot r \Delta *$ & $\cdot / r$ & سلامت \\
\hline$\cdot / \cdot 4^{*}$ & $-\cdot / 1 \wedge$ & --- & --- & --- &.$/ .4^{* *}$ & $-\cdot / 11$ & بحران مالى \\
\hline$\cdot / \cdot 1^{*}$ &.$/ 49$ & --- & -- & --- &.$/ .1^{*}$ & $\cdot / 49$ & حمايت اجتماعى \\
\hline & & & & & & & به تفكر مثبت \\
\hline$\cdot / \cdot l^{*}$ &.$/ 10$ & --- & --- & --- & $\cdot / \cdot 1^{*}$ & $\cdot / 10$ & سلامت \\
\hline$\cdot / \cdot 1^{*}$ & $-\cdot / 44$ & --- & --- & --- &.$\cdot \cdot 1^{*}$ & $-\cdot / 49$ & بحران مالى \\
\hline$\cdot / \cdot 1^{*}$ & $\cdot / \Delta \Delta$ & --- & -- & --- & $\cdot / \cdot 1^{*}$ & $\cdot / \Delta \Delta$ & حمايت اجتماعى \\
\hline
\end{tabular}

$* \mathbf{p}<\cdot / \cdot \Delta$

مالى اثر منفى و سلامت و حمايت اجتماعى اثرات مثبتى بر شادكامى

داشتهاند. براى برآورد مدل ساختارى از روش بيشينه درستنمايى و

شاخصهاى ريشه واريانس خطاى تقريب'، شاخص برازندگى فز آينده'،

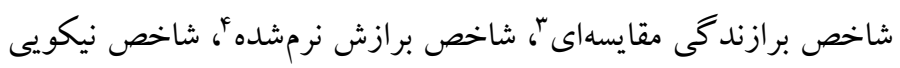
برازشه و شاخص نيكويى برازش تعديل شدهُ استفاده شد. براى شاخصهاى برازندگى برش هاى متعددى توسط متخصصان مطرح شده

4. Normed Fit Index

5 . Goodness of Fit Index

6 . Adjusted Goodness of Fit Index

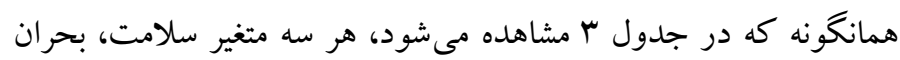
مالى و حمايت اجتماعى اثرات مستقيم و معنىدارى بر عزتنفس، تفكر مثبت و شاد كامى داشتهاند. افزون بر آن، متغيرهاى عزت نفس و تفكر مثبت، اثرات مستقيم و معنى دارى بر شاد كامى داشتهاند. همجنين نتايج نشان داد كه ب متغير سلامت، بحران مالى و حمايت اجتماعى بر شادكامى زنان ميانسال اثر غير مستقيم و معنىدارى دارند. اين به گونهاى بود كه بحران

1. Root Mean Square Error of Approximation

2. Standardized Root Mean Square Residual

3 . Comparative Fit Index 
بسيار مطلوب و كوجکكتر از // بر برازش مطلوب دلالت دارد

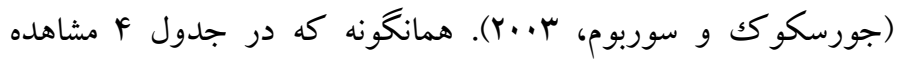
مىشود، اكثر شاخص هاى برازش مدل نهايى مناسب و در حد مطلوب قرو قرار

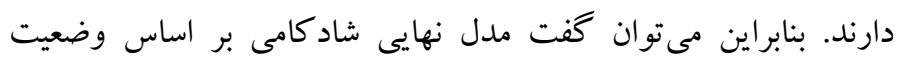
سلامت، بحران مالى و حمايت اجتماعى با نقش واسطهاى عزتنفس و تفكر مثبت از برازش مطلوب داده - مدل برخوردار است. مدل نهايى و و جدول شاخص هاى برازش به شرح جدول F مىباشد.
است. براى مثال، مقدار مساوى يا كمتر از هـ/• براى ريشه واريانس خطاى

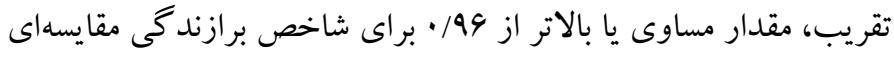
و برازش نرم شده، مقدار مساوى يا كمتر از V•• براى بـ ريشه استاندارد

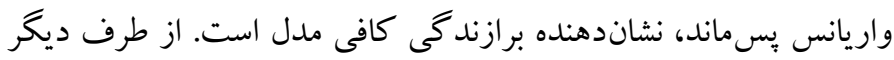

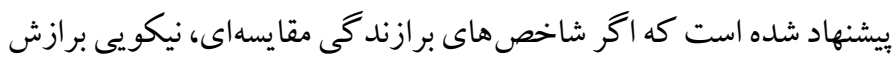

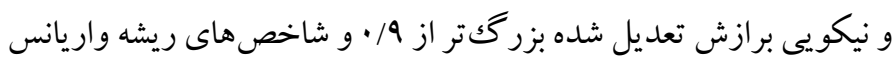

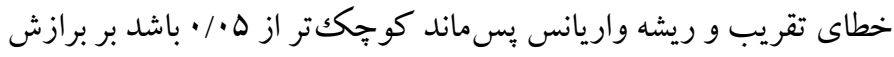

جدول ع. مقادير شاخصهاى نيكويى برازش مورد مشاهده و مورد انتظار

\begin{tabular}{|c|c|c|c|c|}
\hline مقدار مطلوب & مقدار قابل قبول & مقدار بدست آمده & شاخصهاى برازش & رديف \\
\hline & & $\Lambda F / Y V \Delta$ & $\chi^{2}$ & 1 \\
\hline$<\cdot / \cdot \Delta$ & ه/ • الى ^••/ & $\cdot / \cdot M$ & ريشه واريانس خطاى تقريب & r \\
\hline 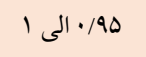 & 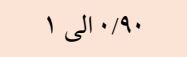 &.$/ 91$ & شاخص برازش نرمشده & r \\
\hline بالاتر از •a/. & بالاتر از •9/· و 1 & $\cdot / 9$ & شاخص برازندگى فزاينده & f \\
\hline ـه • • الى 1 & .9. • الى 1 &.$/ 91$ & شاخص برازندگى مقايسهاى & $\Delta$ \\
\hline 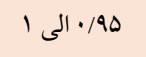 & ـ/9. • الى 1. & $\cdot / 9$ & شاخص نيكويى برازش & 4 \\
\hline 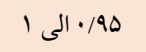 & 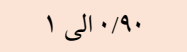 & $\cdot / 19$ & شاخص نيكويى برازش تعديل شده & $\checkmark$ \\
\hline
\end{tabular}

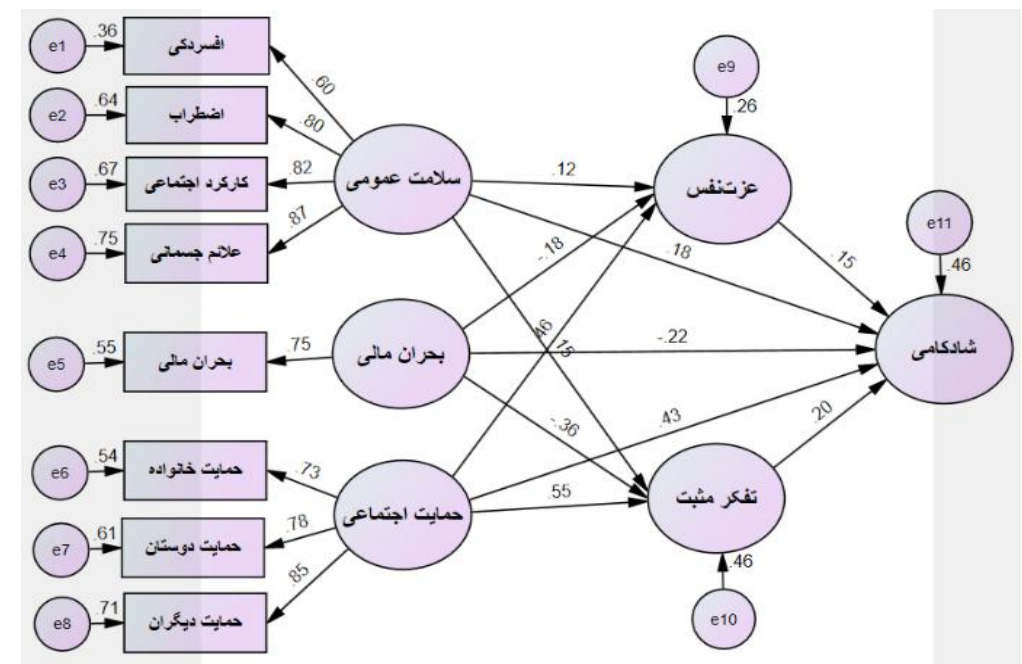

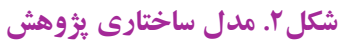

اثر مثبت و مستقيم و معنى دارى دارد. اين در حالى بود كه بحر ان مالى اثر بحث و نتيجه تيرى منفى و مستقيم و معنىدارى داشت. از سويى نتايج نشان داد وضعيت هدف از بثزوهش حاضر ارزيابى مدل ساختارى شاد كامى بر اساس وضعيت سلامت، بحر ان مالى و حمايت اجتماعى به واسطه عزتنفس و تفكر مثبت سلامت، بحران مالى و حمايت اجتماعى با نقش واسطهاى عزتنفس و و

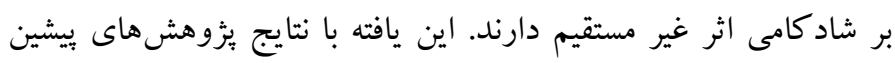

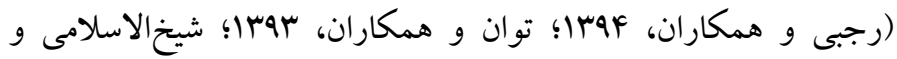

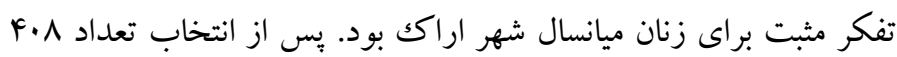

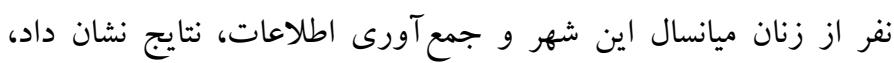

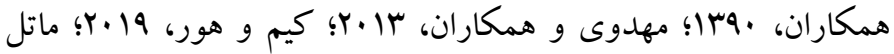

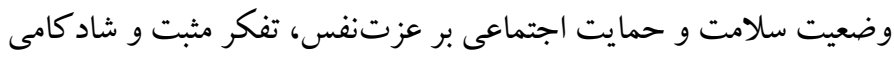


كه فرد از وضعيت مالى مناسبى برخوردار نباشد، نمىتو اند به آينده خوشبين

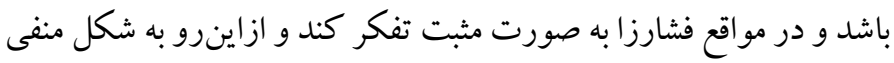

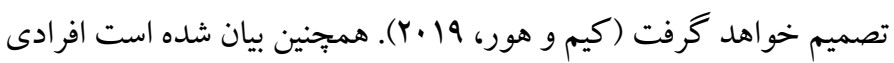

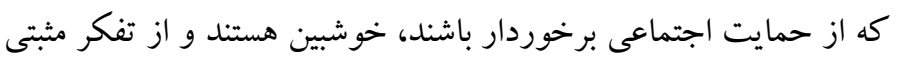

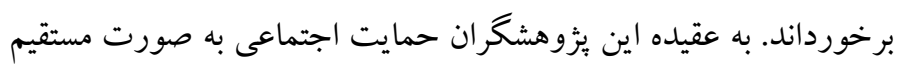

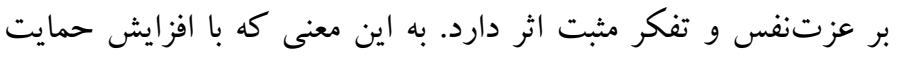

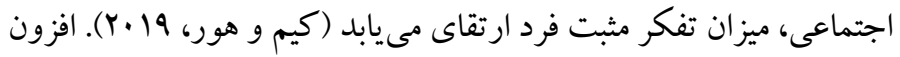

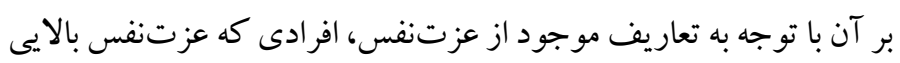

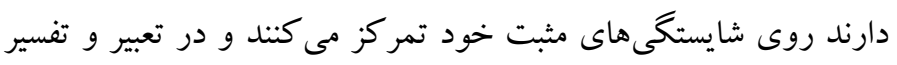

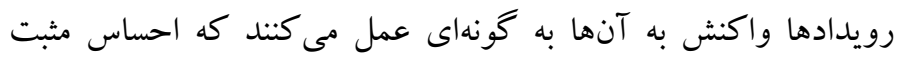
خودارزشى را در خود حفظ كنند و به طور طبيعى احساس خودارزشى و

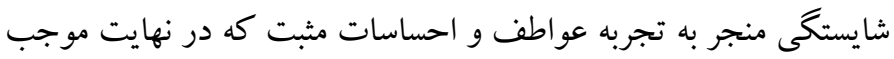

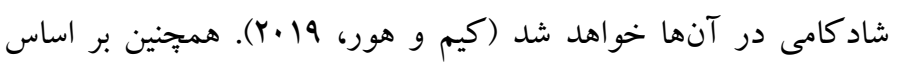

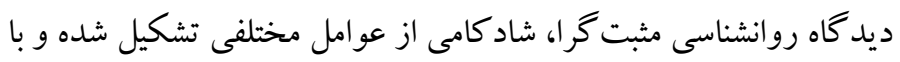
عوامل متعددى در ارتباط است. هيجانات مثبت و نبود هيجانات منفى از اجزاء اصلى شادكامى محسوب مىشوند. در واقع شادكامى به تفسيرى مثبت و خوشبينانه از رويدادهاى روزمره زندگى منجر مى شود. بنابراين

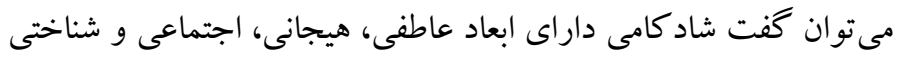

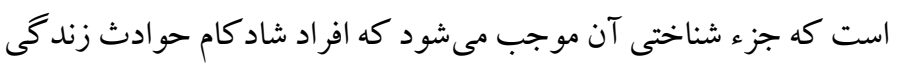
و روزمره را طورى تعبير و تفسير كنند كه منجر به خوشبينى آنها شود

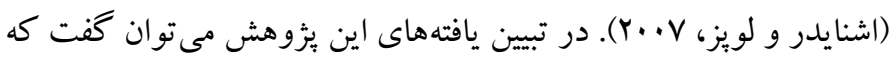

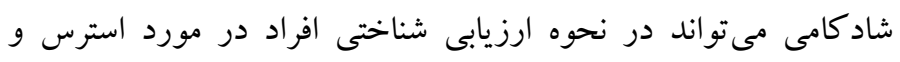

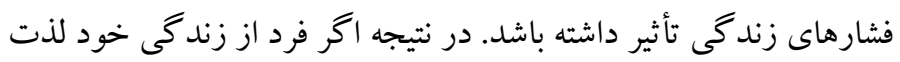

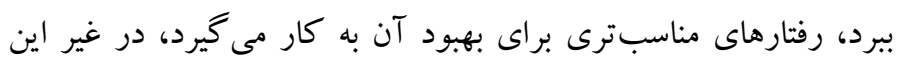

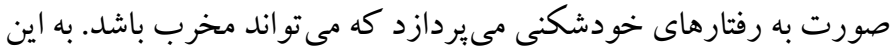
طريق، رفتارهاى سلامت يكك بيشبينى كننده مؤثر در بروز شاد كامى است. بنابر اين زمانى كه افراد از سلامت مناسبى برخوردار باشند و بتو انند همر استا با اين سلامت، به ارزشمندى و عزتنفس خود نيز توجه نمايند، ميزان

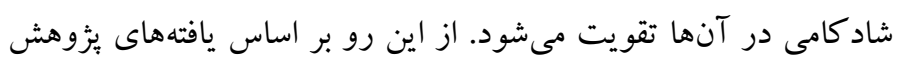

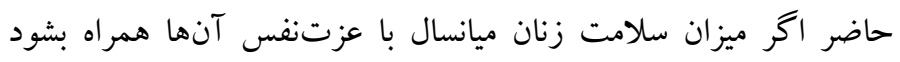
موجبات شاد كامى در آنها تقويت مىشود. همجنين زمانى كه افراد در وضعيت سلامتى مناسبى قرار دارند، بهتر مى توانند تفكر كنند و تصميم
اندرسون و همكاران، 19 ·r؛ باجاج و همكاران، 19.r) همسو بود. در اين يُّوهش سه متغير سلامت، بحران مالى و حمايت اجتماعى اثر مستقيم و

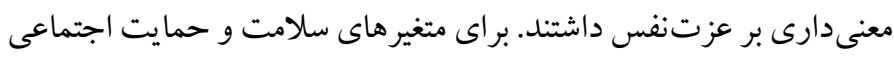

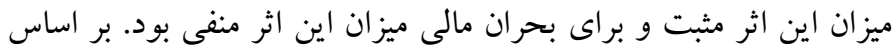

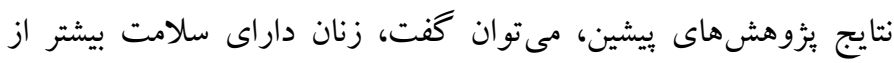

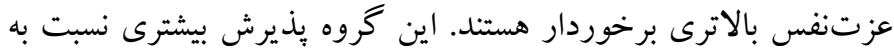

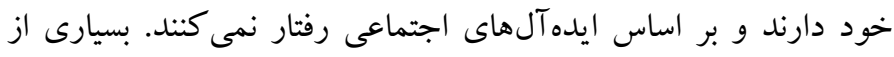
يُزوهشخران عزتنفس را جنبه مركزى سلامت دانسته و آن را اساسى ترين نياز براى سلامت و بخصوص سلامت روحى مى دانند (مهدوى و همكاران،

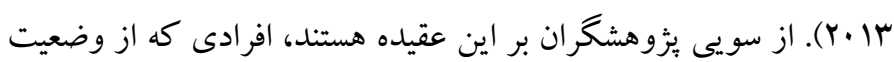
مالى مناسبى برخوردار نيستند، داراى عزتنفس بايينى هستند. اين نتيجه

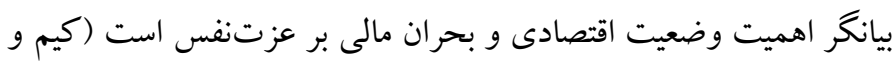

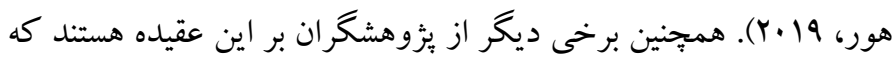

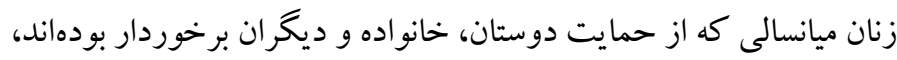
عزتنفس بالاترى را ززارش كردهاند. به نظر مىرسد كه مقدار و كيفيت

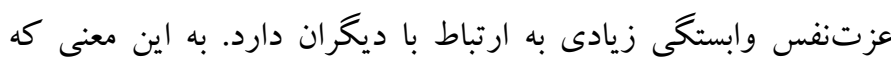

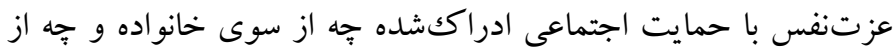

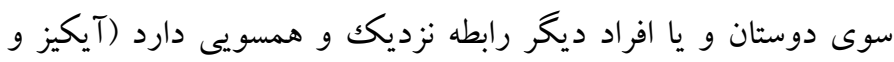

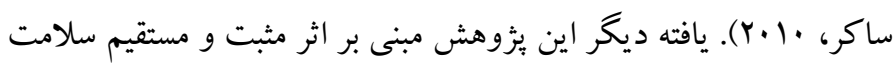
و حمايت اجتماعى و اثر منفى و مستقيم بحر ان مالى بر تفكر مثبت بود. از

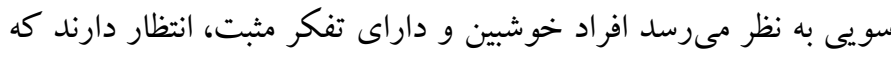
در آينده بيامدهاى مثبت براى آنها اتفاق بيفتد و همين اطمينان به آينده، باعث ايجاد احساس مثبت در فرد مىشود و در نتيجه سلامت عمومى وى بـ بـ

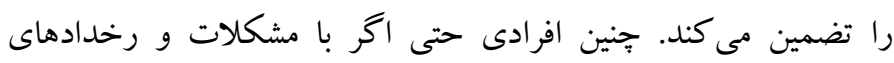

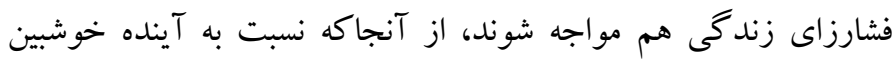

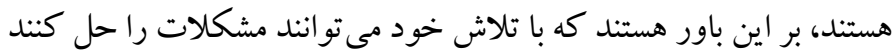

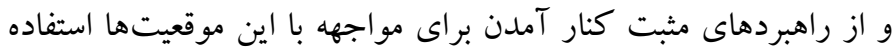

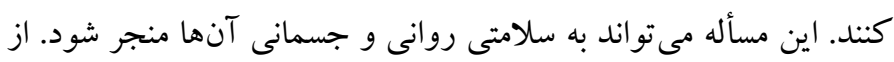
اينرو خوشبين بودن و داشتن تفكر مثبت، باعث افزايش مقاومت سيستم

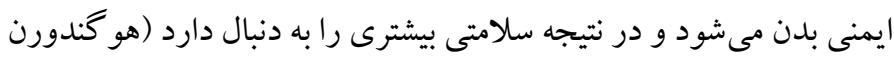

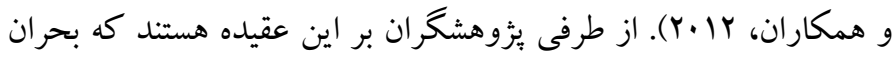

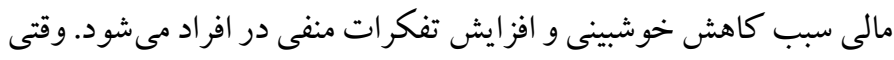


روش يُزوهشى است. در اين يُزوهش نمونه گيرى با توجه به جنسيت

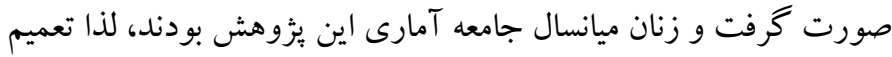

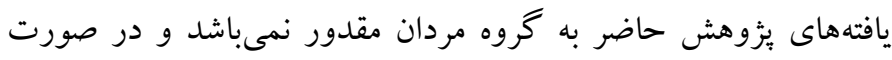
تعميمدهى بهتر است جوانب احتياط رعايت شود. بر اساس اين محدوديتهاى بيشنهاد مى شود اين تحقيق بر روى زنان ميانسال انجام شد و بيشنهاد مىشود بر روى مردان و ساير سنين كه قابليت اجرا دارد، اجرا

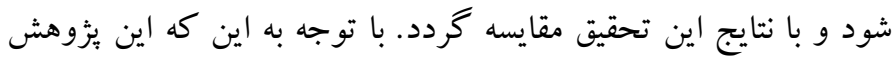
بصورت همبستخى اجرا شده است، لذا جهت كسب نتايج دقيق تر بيشنهاد

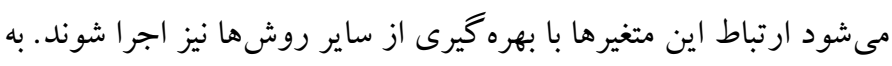

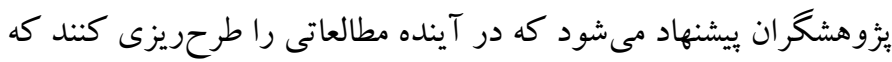

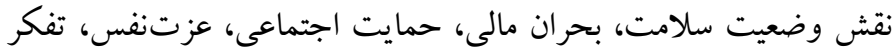

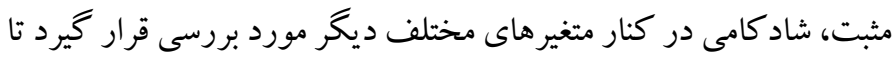

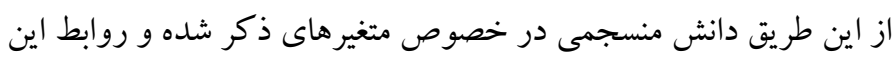

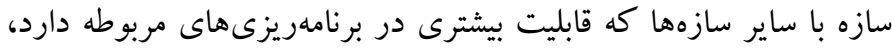
حاصل شود. با توجه به برجسته بودن نقش شاد كامى در بين زنان ميانسال،

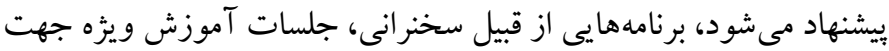

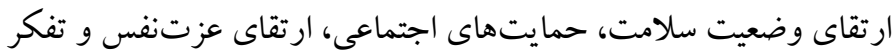

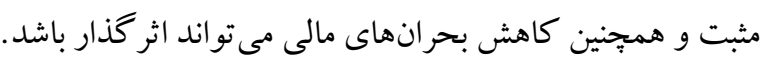

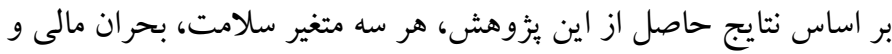

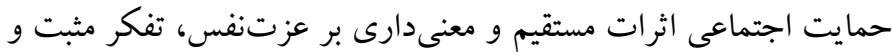
شاد كامى داشتهاند. افزون بر آن، متغيرهاى عزتنفس و تفكر مثبت، اثرات

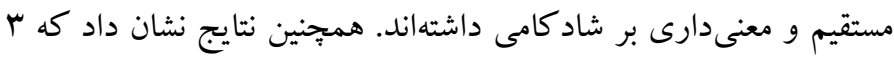
متغير سلامت، بحر ان مالى و حمايت اجتماعى بر شاد كامى زنان ميانسال اثر

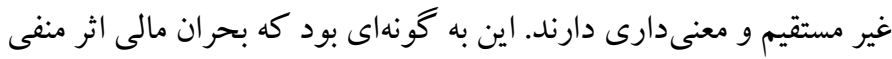
و سلامت و حمايت اجتماعى اثرات مثبى بر شادكامى داشتهاند. بنابراين مى توان نتيجه كرفت دو متغر عزتنفس و تفكر مثبت نقش واسطهاى در ارتباط بين سلامت، بحران مالى و حمايت اجتماعى با شاد كامى داشتهاند و

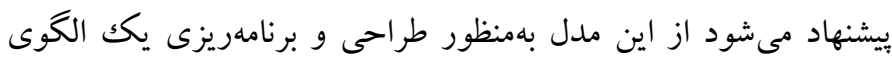
مداخلهاى روانشناختى با هدف ارتقاى شاد كامى زنان ميانسال استفاده شود. بنابراين بر اساس يافتههاى حاصل از اين مدل مى توان، آموزشهايى براى تقويت شادكامى زنان ميانسال ارائه كرد. علاوه بر آن با توجه به اهميت

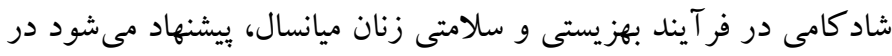

بحيرند و نسبت به آنجه در آينده اتفاق مىافتد، خوشبين تر هستند و اين امر موجب ايجاد شادى و نشاط در آنها مىشود. افزون بر آن زمانى كه زنان

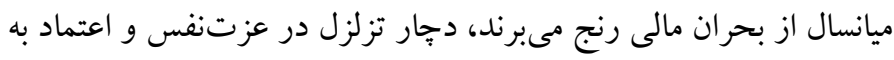
نفس مىشوند كه اين امر مىتواند به عدم شاد بودن و شاد زيستن منجر شود. به عبارتى بريشانى مالى به خودى خود باعث كاهش شادى در زنان

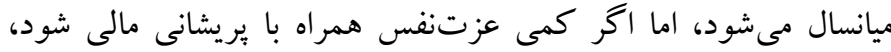
مى تواند تا حدودى ميزان اثر بحران مالى بر شادكامى را كاهش دهد.

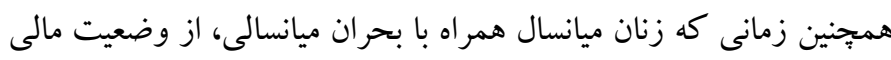
مناسبى برخوردار نباشند و براى مسائل مالى دهار نوعى بريشانى باشند، بجاى تمركز بر تفكرات مثبت، به مسائل منفى و بيامدهاى حاصل از اين وضعيت فكر مى كند كه اين امر باعث مىشود در ميزان شاد كامى آنها

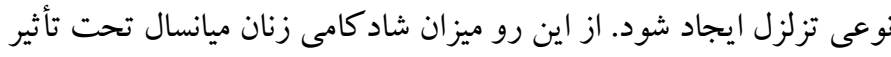

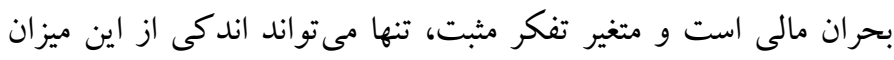

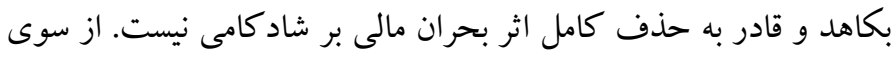

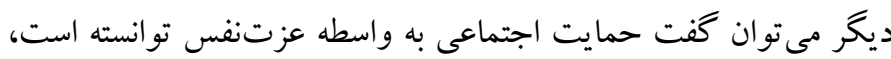
اثر غيرمستقيم و معنىدارى بر شاد كامى داشته باشد. بنابر اين زمانى كه زنان

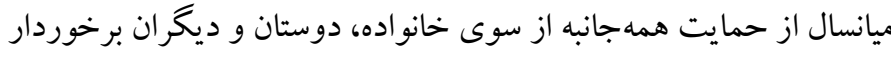

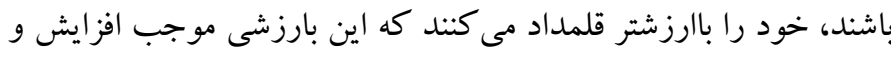
ارتقاى اعتماد به نفس و عزتنفس در آنها مى شود و اين امر به نوبه خود، ميزان شادى را در آنها تقويت و رشد مىدهد. همجِنين زمانى كه حمايت اجتماعى زنان ميانسال مناسب باشد، اين حمايت تفكر مثبت را در بیى داشته كه خود اين دو سازه مى توانند موجبات شاد كامى آنها را در زندكَ فر فراهم

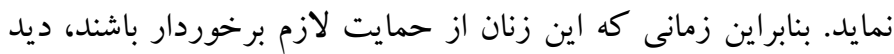

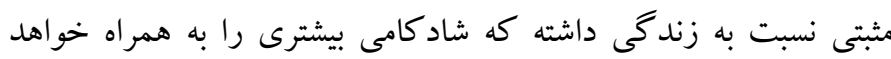

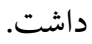

اين يزووهش خالى از محدوديت نبوده است. يكى از محدوديتهاى مطالعه حاضر آن است كه يافتهاى بدست آمده از طريق برسشنامه و به صورت خود ززارشدهى توسط شخص بدست آمده و مشخص نيست تا جه اندازه

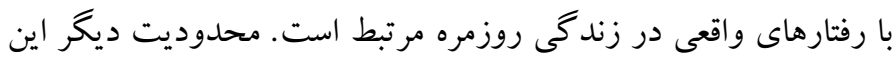
يُزوهش مربوط به تعميمدهى نتايج است. به اين معنى كه نمى توان يافتههاى

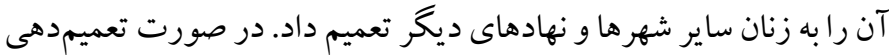

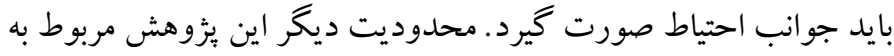


IR.IAU.ARAK.REC.1399.004 مىباشـد. مشـار كت كنند كان آكاهانه و داوطلبانه در ئزوهش مشار كت نمودند. اصل رازدارى در يُوهش رعايت شد.

حامى مالى: اين يزٔوهش در قالب رساله دكترى و بدون حمايت مالى مىباشد. نقش هر يكك از نويسند كان: نويسنده اول محقق اصلى اين يثوهش است. نويسنده دوم استاد راهنما و نويسند كان سوم و جِهارم استادان مشاور رساله مىباشند. تضاد منافع: نو يسند كان هيج تضاد منافعى در رابطه با اين بثزوهش اعلام نمىنمايند. تشكر و قدروانى: نويسند گان بدين و سيله از اساتيد راهنما و مشاوران اين تحقيق و نيز از كليه شركت كنند كان در اين يثوهش به خاطر صبر و بردبارى كمال تشكر و قدردانى رادارند.
رسانههاى آموزشى، اجتماعى و ارتباطى به اصول شادكامى، انواع حمايتهاى اجتماعى، وضعيت سلامت، بحر ان مالى، عزت نفس و تفكر مثبت و بيشايندهاى مؤثر بر آن يرداخته شود و به عنوان يكك حركت ملى به آن نكريسته شود تاعموم مردم بخصوص زنان ميانسال تغيرات لازم را در خود به و جود آورند. ملاحضات اخلاقى يبيروى از اصول اخلاق يثزوهش: اين مقاله بركرفته از رساله دكترى نويسنده اول در

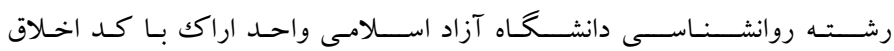




\section{References}

Akbari-Balootbangan A \& Rezaei AM. Construction and Validation to Self-Discovery Scale (SDS) Based on Different Theories of Personality in Students. Journal clinical psychology. 2015; 6(3): 55-68. [In Persian] [Link]

Arampatzi E, Burger MJ, Veenhoven R. Financial distress and happiness of employees in times of economic crisis. Applied Economics Letters 2015; 22(3): 173179. [Link]

Asgari S, Hojatkhah M, Heydarbeygi M. Relationship of family communication patterns, perfectionism and social support with academic self-efficacy among female high school students. Journal of psychological science 2016; 14(56): 557-581. [In Persian] [Link]

Avarandeh M, Eftkharsadi Z, Bakhtearpour S, Hidari A, Askari P. The causal relationship spiritual experiences happiness through marital satisfaction. Journal of psychological science 2019; 18(78): 719726. [In Persian] [Link]

Bajaj B, Gupta R, Sengupta S. Emotional stability and self-esteem as mediators between mindfulness and happiness. Journal of Happiness Studies 2019; 20(7): 2211-2226. [Link]

Chung PJ, Chiou CJ, Chou FH. Relationships between health status, depression and cognitive functions of institutionalized male veterans. Archives of gerontology and geriatrics 2009; 49(2): 215-219. [Link]

Dehshiri GH, Akbari Balootbangan A, Najafi M, Moghadamzadeh A. Psychometric Properties of the Oxford Happiness Questionnaire Short Form in University Students. J of Educational Measurement and Evaluation Studies 2016; 5(12): 9-26. [Link]

Freitas FA, Leonard LJ. Maslow's hierarchy of needs and student academic success. Teaching and Learning in Nursing 2011; 6(1): 9-13. [Link]

Gana K, Alaphilippe D, Bailly N. Factorial structure of the French version of the Rosenberg Self-Esteem Scale among the elderly. International Journal of Testing 2005; 5(2): 169-176. [Link]

Goldberg DP, Hillier VF. A scaled version of the General Health Questionnaire. Psychological medicine 1979; 9(1): 139-145. [Link]

Graham C. Gender and Well-Being around the World: Some Insights from the Economics of Happiness Carol Graham and Soumya Chattopadhyay the Brookings Institution March 2012. [Link]
Hani Asl Hizani A \& Khan Mohammadzadeh Z. Comparison of social skills, positive thinking skills and problem-solving methods in male and female students at the 3rd degree of high school in Zahedan. Sociology of Education Journal. 2018; 11(11): 8898. [In Persian] [Link]

Heizomi H, Allahverdipour H, Jafarabadi MA, Safaian, A. Happiness and its relation to psychological wellbeing of adolescents. Asian journal of psychiatry 2015; 16(11): 55-60. [Link]

Hills P, Argyle M. The Oxford Happiness Questionnaire: a compact scale for the measurement of psychological well-being. Personality and individual differences 2002; 33(7): 1073-1082. [Link]

Hogendoorn SM, Prins PJ, Vervoort L, Wolters LH, Nauta $\mathrm{MH}$, Hartman CA, ... Boer F. Positive thinking in anxiety disordered children reconsidered. Journal of anxiety disorders 2012; 26(1): 71-78. [Link]

Ikiz FE, Cakar FS. Perceived social support and selfesteem in adolescence. Procedia-Social and Behavioral Sciences 2010; 5(12): 2338-2342. [Link]

Ingram RE, Wisnicki KS. Assessment of positive automatic cognition. Journal of consulting and clinical psychology 1988; 56(6): 898-902. [Link]

Joreskog KG \& Sorbom D. LISREL 8: User's Reference Guide. Chicago: Scientific Software Inc 2003. [Link]

Kim SJ, Hur MH. Understanding of Factors Influencing Happiness of Middle-Aged Women in Korea Based on Maslow's Hierarchy of Needs. Psychiatry investigation 2019; 16(7): 539. [Link]

Kline P. Personality (Psychology Revivals): Measurement and Theory. Routledge 2015. [Link]

Kurihara $\mathrm{H}$. Effects of $\mathrm{CO} 2$-driven ocean acidification on the early developmental stages of invertebrates. Marine Ecology Progress Series 2008; 373(5): 275 284. [Link]

Liu B, Floud S, Pirie K, Green J, Peto R, Beral V, Million Women Study Collaborators. Does happiness itself directly affect mortality? The prospective UK Million Women Study. The Lancet 2016; 387(10021): 874-881. [Link]

Madhi S, Najafi M. The relationship between spiritual well-being and hope with quality of life, and happiness in older adults. Journal of psychological science 2018; 17(65): 78-94. [In Persian] [Link]

Mahdavi A, Ahmadi M, Nadermohamadi M, Adham D. The relationship between mental health and selfesteem in students of medical sciences. Journal of 
Society for development in new net environment in $B \& H$ 2013; 7(1): 151-157. [Link]

Matel-Anderson DM, Bekhet AK, Garnier-Villarreal M. Mediating effects of positive thinking and social support on suicide resilience. Western journal of nursing research 2019; 41(1): 25-41. [Link]

McLeod S. Erik Erikson. Retrieved August, 9, 2013. [Link]

Mercola J. Optimism may protect against heart disease. Psychosomatic Medicine 2002; 82(2): 102-111. [Link]

Mihalcea R, Liu H. A Corpus-based Approach to Finding Happiness. In AAAI Spring Symposium: Computational Approaches to Analyzing Weblogs 2006 (pp. 139-144). [Link]

Miles J, Shevlin M. Applying regression and correlation: A guide for students and researchers. Sage 2001. [Link]

Paterson K. What's positive thinking? Indiana police 2008; 151(3): 26-300. [Link]

Prawitz A, Garman ET, Sorhaindo B, O'Neill B, Kim J, Drentea P. InCharge financial distress/financial well-being scale: Development, administration, and score interpretation. Journal of Financial Counseling and Planning 2006; 17(1): 1-17. [Link]

Rajabi GR, Alibazi H, Jamali A, Abassi G. Relationship between Self-esteem, Social Support with Mental health in Shahid Chamran University students of Ahvaz. Journal of Educational Psychology Studies 2015; 12(21): 83-104. [Link]

Rosenberg M. Society and the adolescent self-image. Princeton university press 2015. [Link]

Salimi A, Jokar B \& Nikpoor R. Internet communication in life: Investigating the role of perceived social support and loneliness in Internet use. Psychological Studies. 2009; 5(3): 81-102. [In Persian] [Link]

Seligman AI. Block by block: Neighborhoods and public policy on Chicago's West Side. University of Chicago Press 2005. [Link]

Seligman ME. Positive psychology, positive prevention, and positive therapy. Handbook of positive psychology 2002; 2(2002): 3-12. [Link]

Sheikholeslami R, Nejati E, Ahmadi S. Prediction of components of happiness by self-esteem and marital relationship in married women. Journal of Women in Culture and Art 2011; 3(1): 39-54.. [In Persian] [Link]

Snyder CR, Lopez SL. Positive psychology: The scientific and practical explorations of human strengths. Sage
Publications, Thousand Oaks, London, New Delhi 2007. [Link]

Taghavi SM. Validity and Reliability of General Health Questionnaire. Psychology J. 2002; 5(4): 381-398. [In Persian]. [Link]

Tavan B, Jahani F, Rafeei M. The Relationship between Self-esteem and Happiness among Students of Arak University of Medical Sciences. Iranian Journal of Medical Education 2014; 14(6): 474-482. [In Persian] [Link]

Verme P. Happiness, Freedom and Control. Journal of Economic Behavior and Organization 2009; 71(3): 146-161. [Link]

Vishalakshi KK, Yeshodara K. Relationship between selfesteem and academic achievement of secondary school students. Education 2012; 1(12): 83-84. [Link]

Wills TA, Ainette MG. 20 Social Networks and Social Support. Handbook of health psychology 2012; 465472. [Link]

Wongpakaran $\mathrm{T}$, Wongpakaran $\mathrm{N}$, Ruktrakul R. Reliability and validity of the multidimensional scale of perceived social support (MSPSS): Thai version. Clinical practice and epidemiology in mental health: CP \& EMH 2011; 7(10), 161-166. [Link]

Zimet GD, Dahlem NW, Zimet SG, Farley GK. The Multidimensional Scale of Perceived Social Support .Journal of Personality Assessment 1988; 52(3): 30-41. [Link] 